\title{
3. Key streams in philosophical inquiry: a selection and succinct overview for the field of public administration - part II
}

\section{KANT AND THE REVOLUTION OF THE SUBJECT}

Kant's philosophy is a major attempt to set the limit of what is knowable to human rationality. To this purpose, Kant (see Figure 3.1) introduces the distinction between phenomenon and noumenon, a distinction which is the lynchpin of his philosophical system. Phenomenon is here defined as the thing as it appears (the term derives from the Greek phainesthai). The term noumenon ${ }^{1}$ refers to the thing in itself, the thing 'as it is', which is also the thing as thought by the intellect. In order to better grasp this passage, it is useful to recall that, as the Greek philosophy unveiled, being can be properly understood only within the horizon of thought. The term noumenon derives from the Greek noein, which means 'to think', and according to Kant, the noumenon is something we can think but we cannot know. If the reader is confused about it, s/he may perhaps be comforted by the fact that Kant himself strove with this notion, which is part and parcel of his philosophical system. Moreover, this problematic issue was exactly the point of lever used by idealist philosophers just a few years after Kant's passing away for turning Kant's philosophy entirely upside down by establishing a (dialectical) identity between the thinking subject and the thought thing, and by means of this to overcome the limits posed by Kant to human knowledge. According to Kant, human knowledge can only be restrained to phenomena, albeit in a sense profoundly different from empiricism. Things in themselves can only be grasped by an original intellect (God) in the act in which it poses them into being (it creates them), but not by human beings.

Knowledge is about 'correct' judgements by the reason, and a judgement is a connection of two concepts, one being the noun and one the predicative: what is claimed about the subject of the sentence. Kant outlined a typology of judgements. What is predicated about the subject of the sentence may be implicit in the noun (for example, that all bodies are extended because corporality entails 
extension $^{2}$ ); these judgements are called 'analytical'. Alternatively, what is predicated about the noun may not be implicit in the noun (for example, that all bodies are heavy); these judgements are called 'synthetic'. Analytical judgements are universal and necessary, but do not add to knowledge because what is known was already implicit in the subject of the sentence. Synthetic judgements add to knowledge by predicating of the subject of the sentence something that was not already implicit in it. Judgements may then be before experience ('a priori') or after experience ('a posteriori'). We may then have different categories of judgements. First, analytical judgements a priori: these are universal and necessary, but do not add knowledge because what is predicated of the subject of the sentence was already implicit in the subject, nothing was added through experience; they are in a sense tautological. Then we have synthetic judgements a posteriori that add knowledge -and through experience, something is predicated of the subject of the proposition, but not in a universal and necessary way. The question for Kant thus became whether propositions that both add knowledge and are universal and general in kind are possible. The answer to this question has brought about a Copernican revolution in thought (Kant explicitly referred to his philosophy as bringing about a Copernican revolution in knowledge of the kind that Copernicus brought about in cosmology when discovering that it is the Earth that revolves around the Sun, and he was conscious that after him philosophy would not have been the same any more).

The revolution (in the etymological sense of the Latin revolvere: to turn things upside down) brought about by Kant can be outlined as follows (Kant, 1781/1787). Rather than being the subject to revolve around the object, that is, rather than being the subject trying to discover the properties or laws of the object, it is the object that revolves around the subject, it is the object that must adapt to the properties of the subject that knows it. The categories, that is, the modes and conditions of being that for classical metaphysics were the conditions of Being as such, are for Kant the conditions of the knowability of objects by the subject (he refers to these categories with the term 'transcendental', borrowed from classical metaphysics but re-interpreted in the sense we have just specified). These are conditions of the object only in relation to the subject and as posed by the subject.

This assertion has powerful implications, for example for the notions of space and time, although not altogether new because other philosophers had already dealt with similar perspectives: ${ }^{3}$ space stems from the relations between things, time from the succession of things. In Kant's philosophical conception, time is not in things; instead it is in the subject that knows things phenomenologically. More specifically, time is the form of the intuition of all phenomena after they are perceived by the subject and hence become interior to the subject. Likewise, space is the form of all the external phenomena, of 
all phenomena before they are caught by the senses (and then become 'interior' to the subject). Things are in space and time because the subject orders them in space and time. Space and time do not exist outside the subject. The other categories of being (in classical metaphysics) are also not properties of the object but forms of the subject. Categories like possibility/impossibility, necessity/contingency, existence/inexistence, causality and dependence (cause-and-effect), and the others (for which Kant worked out a frame, identifying twelve categories and relating them to the kinds of judgements the subject can formulate. These categories are grouped into four classes: quantity, quality, relation and modality) are therefore forms whereby the knowing subject orders phenomena. To re-state: categories are not leges entis (laws of the entity), but leges mentis (laws of the mind): ways in which the mind knows the entity.

If the foundation of the object is in the subject (the object supposes the subject), then every representation (perception) of the object in the subject presupposes a unity of the subject which remains itself, immutable in the face of the mutable representations that 'flow' on it (Kant refers to it as 'transcendental apperception'). This is also the unifying point of all the syntheses that the thinking subject operates (that is, of all the judgements made by the subject according to the twelve categories) and it is also referred to as the 'I think'. This is not the individual 'I', but rather the structure whereby every subject capable of rational knowledge is a thinking subject, it is what makes it a rational subject.

To summarise, perception by the subject (experience) has two forms - space and time - and intellect has twelve categories. Together they shape the conditions of knowing. This, for Kant, is how we know and all we can know.

One key consequence is that human knowledge is confined to phenomena. In this regard, Kant argues that three key ideas - that of God, soul and world - are unknowable to the human being. We cannot demonstrate the existence of God, nor can we demonstrate the non-existence of God. We cannot know the soul as an ontological substance; we can only be conscious of the activity of thinking (the 'I think'), but not of the noumenic substance of our own 'I' (because it transcends experience). We cannot know the world, intended not as the physical world but as the totality of things and their causes. (We may also add that this statement is and remains a significant caveat to modern astrophysicists to refrain from jumping from empirical discoveries to ultimate assertions about the beginning, end or nature of the universe.) However, the human being as a rational entity has an irresistible, unstoppable thrust towards transcending experience, and this occurs through the three ideas of God, of the world, and of the soul. These are unknowable and their existence, or non-existence, indemonstrable, but they serve a regulatory function: they provide coherence and 
in a sense an overarching framework to the use of intellect to make judgements about experience.

A big question arises: is it therefore impossible for human beings to be in a deeper relation with the 'things in themselves', beyond phenomena? Are we confined to phenomena without having any 'connection' with things in themselves? For Kant, the answer is that in terms of knowability, things in themselves will always escape the grasp of our mind, but we human beings can accord with them, in a certain sense, through both the moral and the aesthetic $^{4}$ life. In a major attempt in the whole history of philosophy to establish the foundations of morality, Kant introduced and elaborated the notion of categorical imperatives in his 1788 work Critique of Practical Reason (where 'practical' in the title refers to the question 'how to behave' and does not have any utilitarian denotation). Imperatives are something that must be complied with, irrespective of the effects produced by the action: only categorical imperatives are moral duty. For example, a tax-payer may return the self-assessment for fear of sanctions, for simple habit, or with the intention of complying with her/his duty; only in the last case the behaviour is moral. It is interesting to note that the state does not have any means to impose the kind of intentionality with which the tax-payer acts - although it may be more or less effective in ensuring tax compliance. In other words, external entities may hold sway on the actual behaviour of somebody, but not on the intentionality with which an action is accomplished (at least in Kant's conception): intentionality is the realm of morality. Consequently, for Kant, behaviours based on external motives - whether they are the compliance with the customs and mores of the place where you live, or the pursuit of happiness, or the perfecting of yourself through virtue, or the adhering to the Will of God - are heteronomous ways of behaving. Whatever the behaviour is founded on, some external content or motive is not moral in the sense Kant means.

The categorical imperative, or moral law, does not depend on specific contents; it is rather the pure form of a general moral legislation that is valid for each and every being which is rational. For Kant this is also the foundation of liberty: it is the conscience of our ${ }^{5}$ duty, of having a duty to comply with, that makes us conscious of our liberty. Kant would frame this claim more or less this way: 'by doing your duty, you recognise that, for the very reason of being doing your duty, you are free' (otherwise the moral duty would be meaningless). In this way, the human being is told of her/his liberty ( $\mathrm{s} / \mathrm{he}$ recognises to be a free will), even if s/he cannot have any knowledge of its liberty because, as demonstrated in the critique of pure reason, only phenomena are knowable and liberty is not a phenomenon but a thing in itself, and hence it is not knowable. It is through morality that the human being can recognise its liberty and freely adhere to the order of being, to the world of noumena. Adherence to reality beyond phenomena can only be chosen by doing the moral duty. Liberty 
is the independence of our free will from the laws that regulate phenomena. This can be summed up as: 'You must, hence You can' - you must adhere to moral law, hence you are free because you could also have not adhered to moral law. It is from the fact that you did your duty that you can infer that you are free: first comes morality, then freedom - however weird this might appear to us. (Immanuel Kant was the most regular of persons. He lived an extremely regular life doing exactly the same things every day, he did not marry or travel, or have any activity or hobby. He devoted himself totally to philosophy, and yet he was one of the most revolutionary people history has known - in terms of originality of thought.)

One might wonder at this point what formulation of moral conduct capable of guiding practical action can be drawn from this notion of morality. This problem engages Kant who, in the Critique, seems to have wavered a bit to then formulate the criterion that moral behaviour must conform to rules that if they became universal laws rather than just guiding the conduct of the person who formulates them, they would be acceptable. However, drawing practical guidance from this criterion proved not to be immune from contradictions. $\mathrm{He}$ eventually formulated the (most famous) statement of moral conduct 'Act in such a way that you always treat humanity, whether in your own person or in the person of any other, never simply as means, but always at the same time as end' (Kant, 1785/2005). The underlying assumption is that each and every human being belongs to a 'kingdom of ends': every rational being is an end, and must be treated as an end and never as means (better: as means 'only' - as Kant recognises that in everyday circumstances we all need each other in instrumental ways: I need the baker for having fresh bread, the physician when I am ill, etc. - but I must never treat the baker or the physician in only an instrumental way because this would be tantamount to negate the humanity that is in each of them).

The reader may have noticed this represents a sort of 'rational formalisation' of the commandment of mutual love between human beings that can be found in the Gospels. Interestingly, in this regard there is another argument developed by our philosopher: given perfection in morality cannot be achieved in this life, Kant argues that we need to postulate the immortality of the soul in order to enable it to adhere to morality in a total way; the rational being is a moral being and hence it 'must' endure eternally in order to fulfil its very nature of being rational and hence moral. In Christianity, the human being has a natural predisposition to perfection, but is not left to walk all the way to perfection alone, but is instead helped by the incarnate God to fill the (abysmal) gap determined by the original sin. Kant in a sense halts a step before: because the categorical imperative is a regulatory ideal that can never be fully accomplished in this world, it must be postulated that full accomplishment will be 
achieved, and hence that the rational human being will be endowed with the immortality required for perfection to be achievable.

The rational subject, as Kant conceives of it, is limited in terms of what it can know, but it is a 'strong' subject in all other respects, very far from representations of it as the malleable product of societal conditioning depicted by some relativist or post-modernist contemporary philosophical strands. Indeed, this subject - always an end, never just a means - is, we argue, a key term of reference in public governance, public administration and public services management. Kant provides a major attempt to establish a moral foundation of not just individual life but also social life, and hence public life: he then provides a major attempt, and an inescapable one, to the normative foundation of the practice of public governance and administration. Since morality as founded in Kant's philosophy does not depend on any external motive (although it does not exclude those motives which will be influential on actual behaviour but cannot ground morality), the ultimate foundation of the moral behaviour of all the citizens of a political system, and of public servants in particular with regard to public governance, is ultimately grounded in the moral law of always behaving in such a way to treat humanity, whether in one's own person or in the person of any other, never simply as means, but always at the same time as end. This is a universalistic foundation of public governance, applicable anywhere and anytime ${ }^{6}$ in any system of public governance that human (i.e. rational) beings establish.

It should be noticed that for Kant behaviours can comply with external motives, all these lying outside the foundation of morality as Kant intends it. Behaviours driven by external motives are diverse in nature from the behaviours that are patterned on the morality that a rational being is demanded of as such, for its very being a rational being. Compliance with the customs and mores of the place where one lives, the pursuit of happiness, the perfecting of yourself through virtue, or the adhering to the Will of God, are therefore all totally acceptable, and any concrete system of public governance could and should incorporate and be tolerant towards all these behaviours. But it should not assume them as the ultimate foundation of morality and, one might argue, of the moral legitimacy of public governance.

Any attempt to provide grounding to ethics - and notably for the purpose of our book ethical behaviour in the public service - cannot renounce confronting itself with Kant's attempt to an 'absolute' foundation of moral behaviour.

The work of Kant has been hugely influential on philosophy. Similar for other masters of philosophy, it can be stated that his thought is inescapable nobody after Kant can philosophise setting his contribution aside. At the same time, no human philosophy can provide the last word or represent a full stop: his claims have both been resisted from a classical metaphysics viewpoint and turned upside down from the viewpoint of the philosophy of idealism. 


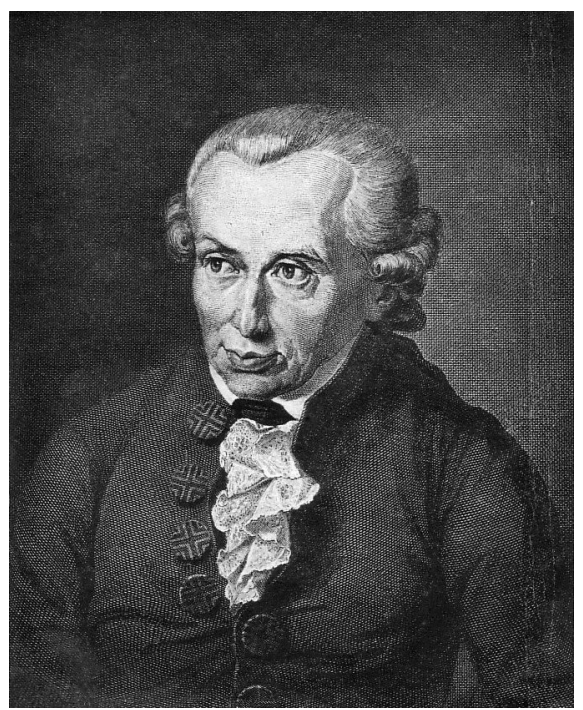

Source: https://en.wikipedia.org/wiki/Archivo:Immanuel_Kant_(portrait).jpg (accessed 17 April 2020).

\section{Figure $3.1 \quad$ Immanuel Kant}

The philosophical debate around the knowability and the very meaning of the 'thing in itself' continued over the subsequent two centuries, and still endures. Philosophical movements like phenomenology (see later) interpret the phenomenon more as a door open - or at least ajar -to the knowledge of things in themselves rather than as a compelling limit. Philosophers rooted in classical metaphysics, like neo-Scholastics, tried to reconcile the subject of Kant with the overall frame of Aristotelian-Thomist metaphysics. However, it is idealism that, only a few years after the passing away of Kant, first challenged his philosophical system, carrying out a major attempt to turn it upside down. It is to this philosophy we now turn.

Implications for PA/Relevance for Philosophy for PA: Kant's 'revolution' in philosophy, that brought the knowing subject and the subject of moral judgement centre stage, has not been without its critiques (as we shall right from the next section); however, it continues to potentially represent a major starting point for any conception of public governance, by providing a grounding for what any human being (indeed, any rational being), hence any and every member of any political community, may be able to know and by providing the moral compass for value-based decisions by any member of the political community: we discuss this possible usage of Kantian philosophy widely at the incipit of both Chapter 4 and Chapter 6 (from the angle of the moral subject 
and the knowing subject respectively): the Kantian subject of knowledge and capable of moral judgement can be taken as a starting point of attempts to ground the foundations of public governance.

\section{IDEALISM}

There are two crucial underpinnings of Kantian philosophy: first is the notion of noumenon as the thing in itself, which is the condition of knowability but is not itself knowable to the human being, ${ }^{7}$ and second is the 'I think', the unity of the thinking subject as condition for knowing to occur. ${ }^{8}$ By giving a different interpretation to these two buttresses of Kant's philosophical edifice, idealist philosophers have turned Kantian philosophy upside down.

Idealism is associated chiefly with three philosophers: Johann Gottlieb Fichte, Friedrich Wilhelm Joseph Schelling and Georg Wilhelm Hegel. The thought of each of them has been vetted in countless books, and in the 20th century there has been a reassessment of Fichte's and Schelling's original thought as an autonomous body whose reach goes well beyond the interpretation of it as just a 'preparatory phase' paving the way to Hegel and Hegelism: an interpretation that was indeed spread by the same Hegel and his numerous acolytes, who held a dominant position in German academy over the 19th century. However, the extreme synthesis that we are forced to do in these few pages leads us to focus, exclusively for reasons of brevity, mainly on Hegel's philosophy, whose influence has loomed large over philosophy. The so-called dialectical method he worked out and the derived conception of how history progresses have figured prominently in the humanities and the social sciences since, and also have far-reaching implications for the field of public administration. Hegel's conception of the state has been extremely influential on debates in public governance.

Fichte's philosophy is the starting point of idealism. By providing a revolutionary interpretation of Kant, in the literal sense since he turned Kantism upside down, ${ }^{9}$ Fichte reverses the traditional assumption of classical Aristotelian metaphysics that first something needs to be, then it acts (action follows being; in Latin: operari sequitur esse) into its opposite - it is action that precedes being (in Latin: esse sequitur operari), where the very action that precedes any other is the action whereby the 'I' poses itself in what Fichte calls the principle of identity as I = I, and by posing itself also poses the non-I. Both are contained in the unlimited I that poses all reality by acting. The 'I think' that in Kant was the function of thinking, more methodological premise for rational knowledge to occur than ontological principle, here becomes the absolute foundation of reality: the thinking of the 'I think' establishes reality. This 'I' really deserves the use of the capital letter that the English language attributes to the pronoun designating the first person in the singular (unlike most other languages that 
use the lowercase character for the first person in the singular, for example in French 'je', in Spanish 'yo', in Italian 'io' and so forth).

Schelling adds another key component to the idealist philosophy: ${ }^{10}$ nature is conceived of as the 'non-I', that stands in opposition to the pure 'I think'. ${ }^{11} \mathrm{He}$ then re-interprets the principle of identity (which led Fichte to pose the I = I), taking the move from Spinoza, into an absolute identity of I and non-I in God, and hence arriving at a form of panentheism (that everything is in $\mathrm{God}^{12}$ ). In the last phase of his thought, Schelling profoundly modified his philosophy, especially by re-introducing the distinction (which played a central role in medieval thought) between essence and existence, leading to outcomes that in many respects preconise the dissolution of idealism.

Hegel's philosophy synthesises the absolute 'I think' of Fichte and the nature as non-I of Schelling in a way that trespasses both. The starting point of Hegel's philosophy is the dialectical method and the 'triadic' logic of thesis-antithesis-synthesis that he applies at heights so ambitious that they had probably never been attempted before, nor have since.

Initially conceived of in ancient Greece by the works of the Eleatic school, and elaborated especially by merit of the philosopher Zenon, classical dialectic was brought to its zenith by Plato. But in Hegel's interpretation dialectic acquires a dynamic thrust it did not have in classical metaphysics. Since in Hegel reality is becoming, the three moments of thesis, antithesis and synthesis acquire a specific meaning. Often in Hegel the thesis is seen as an assertion made by the intellect (which for him is static, inadequate to comprehend the inner tissue of reality), then reason (often in Hegel written with the initial in capital: Reason) intervenes to trespass and overcome the limits of the intellect by positing the negation, or contradiction, of the thesis, namely the antithesis. The action of posing the antithesis, in which the thesis seems to dissolve, is the negative function of the reason: this is followed by a positive function of the reason whereby, dynamically, thesis and antithesis as the two opposites are synthesised into a superior unity: the unity of the opposite determinations. This synthesis is the positive function of reason, also called by Hegel 'the speculative moment'. Thesis and antithesis continue to live in the superior synthesis: in fact, Hegel utilises the terms, in the German language, of 'aufheben' (to overcome) and 'aufhebung' (the overcoming) to express the speculative synthesis. The point is that the German term aufheben has three meanings: it indicates the negation of something, as when a law is repealed by a new law; the preservation of something, the securing of something for the future; and the lifting up of something, the putting of something on a higher level. Thesis and antithesis then get overcome yet maintained and ultimately heightened in the synthesis. ${ }^{13}$

Having reached this point, Hegel's famous statement that 'all that is rational is real, all that is real is rational' should not be as a surprise for the reader. 
This is not to be intended as a proposition whereby the predicate (in the first part of the sentence: 'is real') is predicated of the noun (in the first part of the sentence: 'all that is rational'), but as a dialectical synthesis: there is no distinction between rational and real. The rational 'I think' of Kant has now radically changed function: it poses reality, and indeed the 'I think' dynamically is reality, because there are no longer any borders between reality and rationality. Equally, it should be clear why for Hegel the past is never 'past', but it is all kept (preserved) into the successive superior synthesis, every time more perfect (analogously to Spinoza's philosophical system, a key category in Hegel is that of necessity: all that is real is necessary, which also means that all events of history happened by necessity - and each of these necessary events is kept in the ever more perfect progress of history).

To follow the ambitious application that Hegel made of dialectic reasoning, the reader should at this point fasten the seatbelt because Hegel's philosophical system aimed at reaching heights rarely if ever seen before and after him. Indeed, no realm of human history, philosophy, art, religion or any other conceivable aspect of reality is left outside Hegel's philosophical system; with Hegel philosophy is not just placed at the apex but it becomes all-encompassing. Indeed, for Hegel the Absolute Spirit takes full conscience of itself in philosophical speculation, which reaches its apex in his own philosophy: put directly, for Hegel, God fully takes conscience of itself in his (Hegel's) philosophical system (humbleness was not a virtue of our philosopher). We can only hint here to some phases of one of the most intellectually fascinating, genial, ambitious - and often derided - journey that human mind ever conceived. In Logic (1816/1975), Hegel starts from the 'being' of Parmenides as the thesis posed by the intellect ('being' here is for Hegel a static notion), to then conceive of non-being as the antithesis (the challenge or negation posed by reason performing its negative function), to finally interpret Heraclitus's 'becoming' as the synthesis (speculative reason making the synthesis of thesis and antithesis). In this beginning there is already all ontology (Parmenides and Heraclitus), but this commencement (the first dialectical synthesis of Hegel's system) is just one of some thirty stages of the 'Idea in Itself'. The second stage is when becoming gives rise to something determinate (becoming 'makes something happen', and hence produces something determinate), that is, it gives rise to determination. Determination is negated by 'something else', the otherness of something, but the something else of something is always in turn overcome by something else, and so on giving rise to the indeterminate, that is, to the infinite, or the notion of infiniteness. This is the second synthesis in Hegel's philosophical system. Here Hegel makes a detour to emphasise the significance of the infinite and to ridicule all philosophers who claim that the finite is the only reality. For Hegel, any philosophy that attributes true being to finite being as such simply does not deserve the name of philosophy 
(unless this is conceived as just a dialectical moment of a superior synthesis). Contemporary philosophers, who appeal to Hegel for explaining the becoming of being and at the same time claim that the finite is the only reality, should be equipped to wrestle with this peremptory statement made by the German giant of philosophy. ${ }^{14}$

From the infinite, Hegel then moves to the being for itself and the being out of itself: 'the One and the Many' central to the philosophy of Plotinus. This is part of the third stage of dialectical synthesis that Hegel examines. These three stages are just the initial ones of something like thirty stages of what Hegel refers to as the accomplishment of the 'Idea in itself'. One might well consider this to be enough, but the Idea in itself is, in Hegel's system, followed by nine stages of the 'Idea outside of itself', that is, nature. Hegel discusses the whole of the natural world, from space and time as dialectical moments of "place and movement' (which is the synthesis), and so on to systematise the entirety of the physical and biological world (and of physics and biology as disciplines).

And (the reader is advised to keep the seatbelt tightly fastened) all this is just preparatory to the utmost moment, the philosophy of the Spirit or 'Idea that returns in itself'. In this part of his gigantic framework, ${ }^{15}$ Hegel first treats the soul (thereby including all anthropology and psychology), then the whole of history and the foundation of the State (including law, morality and ethics - the last one being the superior moment for Hegel), to then most famously conclude his journey with the renowned statement that art (the arts, from Greek art to Medieval, Renaissance and then Reformed art), religion (from Greek religiosity up to Christianity) and finally philosophy (from Greek philosophy to medieval Christianity up to modern German philosophy as the accomplishment of philosophy) compose the supreme dialectical moments of the Absolute Spirit: in speculative philosophy God itself 'knows, enacts, makes and enjoys eternally' reality as a whole - that is, God itself is now fully revealed to itself. Hegel's journey is vertiginous.

The reader can now respite, unfasten the seatbelt and appreciate why most of the philosophy of the two subsequent centuries has (also) been a reaction to Hegel's extraordinarily ambitious philosophical construction (Hegel, 1807/1977, 1816/1975; see also the collection in Hegel, 1968).

Whatever the criticisms that can be moved to such comprehensive, systematic account of reality, Hegel's historicism and the dialectical method occupy a central place in the humanities and the social sciences. So does one other part of Hegel's thought, namely his conception of the state - the rational state - a theme mainly developed in Philosophy of Right (1821/1991; here we follow mainly the summary in Ryan, 2012, pp. 688-94 in particular). Hegel's approach to the state and its role is - needless to say - triadic. The trio is represented by the constitution, international relations and the stage of world history. The last term is the one that engendered most contention, especially 
where a claim is made that 'peace among nations ... would produce stagnation' (Philosophy of Right, p. 324). This has been interpreted by commentators and critics as legitimating war, and notably the wars later led by the Prussian State (of which Hegel was a citizen), especially after the unification of Germany; in other words, of having legitimated Prussian aggressive nationalism, up to the totalitarian form it later took under Nazi Germany. It is, however, more likely that Hegel simply had a realistic view of war as an instrument of the state, not much dissimilar from the realist tradition in the field of international relations. The point is that when this view is wrapped into the Hegelian framework of the dialectical progress of history in which each and every historical event is interpreted as a necessary stage of the life of the Absolute Spirit, the claim about war salvaging the world from stagnation may definitely look like an outright legitimation of war.

The other element of major interest (for the purposes of this book) of Hegel's conception of the state is his confidence in the administrative capacity of the modern state, a theme worked out in Philosophy of Right (notably $\S \S$ 287-29). Hegel seems to show a great reliance in the capacity of the state to control its territory and efficiently manage its citizens. Indeed, in this frame citizens play mainly the part of 'subjects' of the state; whether enough room is given in Hegel's system to 'citizens as citizens' (in the contemporary liberaldemocratic sense of the notion) is questionable, although arguably this may be a circular relation: the citizen fully becomes a citizen through the state, and an end of the state is providing the conditions for citizenship. What emerges from Hegel's view is the vision of a strong state endowed with a strong administrative apparatus, served by a civil service which becomes a distinct social class: the instruments for building such bureaucratic apparatus delineated by Hegel were to be further worked out - based on profoundly different, though perhaps not so radically as it is often considered to be the case (Tijsterman and Overeem, 2008), philosophical premises - in the thought of a country fellow of Hegel: Max Weber. The vision of the modern state as being endowed with a strong administrative apparatus, independent, or at least endowed with a degree of autonomy from politics, and tasked with both implementing the laws and with contributing to framing new ones based on its capacity to provide impartial advice to political organs, is in many respects still around nowadays, entrenched and deeply enculturated as part of the conception of governance of the contemporary German state and a number of other continental European states (and beyond). Whether the capacities that Hegel purported the state to hold are actually still there in the contemporary continental bureaucracies hollowed out by New Public Management-inspired reforms, slashed by budgetary cuts, poached by powerful transnational corporations controlling assets greater than those of many countries, is an empirical question. However, the vision of the state that Hegel propounded seems to linger and have remained with us two 
centuries later, continuing to permeate contemporary debates (e.g. Tijsterman and Overeem, 2008).

Implications for PA/Relevance for Philosophy for PA: we have seen how Hegel's philosophy of the state can form the basis of a philosophy of PA: a specific way of conceiving of public governance and administration (and notably one in which the bureaucracy does not have to be tamed, like in many liberal conceptions of the state emphasising the protecting of citizens from bureaucratic 'interference' into their lives, but rather the civil service is seen as a constitutive and essential part of a free state: ultimately, a constitutionalist account of bureaucracy and an 'optimistic' view of its role can be ascribed to Hegel's conception of administration); developing such distinctive philosophical conception of PA is not within the remit of this book, which aims at providing an introduction to the use of philosophy for PA (see Chapter 1) - it would be a fascinating task for another book, by other authors (and see Tijsterman and Overeem, 2008, for an insightful revisiting of the contemporary significance of the Hegelian philosophy of administration for contemporary public governance). At another level, it is in Hegel's thought that can be found some of the key roots of conceptions of the state as a central integrating force within society, a key trait of the Rechtsstaat model of state which permeates the basic culture of governance of many contemporary administrative systems across the world (Pierre, 1995, p. 8; Pollitt and Bouckaert, 2017, pp. 60-2).

Hegel is also the author at the roots of the philosophical approach known as historicism, and of a conception of time which still plays a role as a term of reference to be confronted with for virtually any weltanschaung (world view) that can be elaborated: we vet into some implications of conceptions of time and history for PA in Chapter 4.

\section{THE INHERITANCE AND THE OVERCOMING OF HEGEL; MARX AND GRAMSCI}

Judgements of Hegel's philosophy are bitterly divided. As aptly summed up by Ryan (2012, p. 654, who seems indeed to lean heavily towards the critical), 'To those intoxicated by his system, he has seemed to illuminate the universe in ways unparalleled by any other thinker. Those who have thought it all hot air have dismissed him (in Schopenhauer's memorably abusive phrase) as a "nauseating, illiterate, hypocritical, slope-headed scribbler".' Whichever the slant (and for a more positive appraisal of Hegel's inheritance, see Stewart, 1996), the bequest of Hegel is huge.

Soon after his philosophical system came to be formed, he started to have acolytes, especially in Germany where his academic influence burgeoned. It is commonly distinguished between a Hegelian right and a Hegelian left, bitterly divided on two key issues: politics and religion. Whilst the right Hegelians 
generally maintained, in the political sphere, that the Prussian State as it stood embodied the development of the Spirit, the Hegelian left riposted that the Prussian State was just a stage of a larger process and should have been dialectically overcome. In religion, the Hegelian right interpreted Hegel's philosophy as broadly compatible with the dogmas of Christianity, whilst the Hegelian left found Hegel's philosophy irreconcilable with Christendom.

We here focus the thought of one philosopher whose philosophical system at the inception can be ascribed to the Hegelian left, although he later developed an original thought that went beyond Hegelism and occupied large swathes of the philosophical debate and of politics alike during the 20th century: Karl Marx.

To better appreciate the distinctive thought of Marx, it is important to consider the harsh critiques he moved not just to Hegel (with whose system lineages can however be tracked), but also to the Hegelian left (let alone the Hegelian right) and, beyond the Hegelian system, to classical economists like Smith or Ricardo, to the stream of thought of the so-called 'utopian socialism' associated with Babeuf, Saint-Simon, Fourier, Owen (amongst others), and to other forms of socialism like the one advocated by Proudhon (one of the preferred target of the darts of Marx). Marx propounded a scientific socialism that was - for him - different from the socialism of benevolence of the Utopian socialists and Proudhon: it was based on an understanding of the economic bases of societal and cultural-ideological processes, whose proper investigation required the overcoming of classical political economy.

Before we shift from the critique (pars denstruens) to the pars construens of the thought of Marx, some qualifications are required. First, a distinction has been drawn by historians of philosophy between the thought of Karl Marx, to which we refer as Marxian philosophy, and Marxism as an ideology whose huge influence shaped an important part of the history of the 20th century. 'Marxian' refers to interpretations of Marx's original thought. ${ }^{16}$ 'Marxism' is an ideology, or a gamut of ideologies, which spread and had a huge influence during the 20th century. The influence of Marxism on political thought, and hence also on the debate about public governance and the organisation of the public sector, can hardly be exaggerated. It has had a huge influence throughout the 20th century, and entire political regimes have been inspired by interpretations of Marx's thought - and still are, either directly (Cuba) or indirectly (mediated by Maoism and pre-existing conception of governance, notably Confucianism, in China and other countries) at the time this book goes to press. We cannot track these influences within the limits of this book: it would simply be impossible here - it is a task taken up by innumerable other books. Nor can we even hint to the countless books devoted to the analysis of Marxian thought that fill university libraries across the world. We will outline here just 
some key traits of his thought that we deem of most direct significance for the purposes of this book.

A key influence on Marx is another philosopher, Ludwig Feuerbach, and notably his critique of religion. Feuerbach's criticism is rooted in the Hegelian conception of history: in this perspective, the dialectical unity of finite and infinite, of human and divine is assumed, but rather than being the human to be eventually absorbed into the divine as in Hegel, in Feuerbach it is the divine to be interpreted as a projection of the human and be absorbed within the human. This is seen as a historical process, and it represents a major point of difference from the Enlightenment critiques of religion. Those critiques were in many respects metahistorical: the reason of the Enlightenment enables the human species to escape the myths and legends, the prejudices of human infancy and see the world through adult eyes - and for some scholars of that epoch this meant getting rid of the religious phenomenon as something related to the infancy of humankind (for others it meant 'theism', a sort of rational religion; for still others it meant a renewal of the way in which the Christian faith was lived). For Feuerbach, the development of religion is a historically necessary process, which leads to objectivise the suffering of the human species, and in this perspective God is conceived of as the conscience of the human species. ${ }^{17}$ This claim was a powerful influence on Marx, who pursued through his philosophy a sort of turning upside-down of Hegel's framework, starting from the material conditions rather than the Intellect of the 'I think', while keeping the dialectical logic as the key conceptual tool for the explanation of the becoming of things and history.

The dialectical method is central in Marxian thought. He borrows the idea from Hegel, but reverses the perspective: from dialectical idealism into dialectical materialism. History proceeds through contradictions that are solved into superior syntheses, but these occur at the level of the material, concrete, economic conditions - whilst juridical, moral, philosophical, religious ideas are derivatives of these underlying dynamics occurring at the level of the economic structures regulating society. This is probably the key bifurcation where the distinction can be made between those who recognise the contribution of Marx to philosophy and sociology but do not adhere to Marxism as an ideology, and those who adhere to Marxism. For the former group, economic structures and conditions do have an influence on ideas and on the cultural, moral and spiritual life of a community and humankind at large: but these influences are not deterministic, it is not a one-way (from the material conditions - the relations in economic production processes - to the cultural and spiritual), but rather a two-way influence, and the cultural, moral, spiritual dimensions have their substantive autonomy from the economic dimension. For the latter group, instead, the study of economic structures is the key to understanding 
the totality of human phenomena: this assumption is not philosophical - it is ideological.

Marx elaborated other key notions that have entered the philosophical and social science debate, including that of alienation: ${ }^{18}$ the dispossession of the fruit of the labour of the worker by capitalist-dominated structures. ${ }^{19}$ Equipped with these conceptual tools, he famously described history as a struggle between classes for the control of production means. If the bourgeoisie managed to overthrow the ruling noble class of the feudal society (and by gaining control of economic structures to impose its values over the values of the nobility-led medieval age), it was now capitalism to being on the verge of collapsing, by generating with its own hands the proletariat, which, once it had taken conscience of its condition of alienation, would have led to a revolution, spreading from the countries where capitalism was more advanced to the rest of the world. At first, the state would have controlled the means of production, but that would have been just a transition phase towards a world without private property, without division between manual and intellectual work, without alienation and, notably, without the state; a return of the human being to her/his fully human condition. A famous slogan coined by Marx is 'to everybody according to his needs, everybody in accordance with his capacities' (Critique of the Gotha Program, 1875).

Marxian forecast has not materialised, though, and the reasons for this have been widely debated (and we can here only refer the reader to innumerable books on the topic); but what is left of Marxian analytical apparatus for the study of the field of PA? I will take an illustrative example that combines: an original interpretation of Marx, the one developed by the Italian thinker Antonio Gramsci, to show how some of the concepts originally developed by Marx may bear fruits as analytical tools in contemporary governance and PA debates. The starting point is the work of the Marxian philosopher Antonio Labriola, who interpreted the dominance of the economic moment as the influence of last instance (some might interpret it as a sort of concession to the Marxian orthodoxy), but he argues that the interrelations between economic structures and cultural superstructures are two-way and articulate, rather than being one-way and deterministic. This is a starting point for Gramsci (his main work, Lettere dal Carcere [epistles from jail], was written in the 1930s whilst Gramsci was in jail, during the Mussolini regime and was published posthumously; see Gramsci, 1947). He theorised that a class, in order to become dominant, must first shape common sense and common wisdom: it must permeate the superstructure with its values, it must infuse its values in the larger 'civil society' (a notion and political science category that he contributed to introduce into political thought, and which he interpreted as opposed to the 'narrower' political society). Only later and as a consequence of this process of acquisition of ideological dominance in the national culture, 
the class that wins the battle of the values will also take control of the political society, and of the state apparatus by achieving the office of government. In this vision, intellectuals become an instrument of cultural domination: they are defined by Gramsci as 'organic intellectuals', where 'organic' means part and parcel of the political party that represents the class and whose function is to elaborate and spread the values of the political party to which they belong by acting as the elaborator in intellectual forms of the needs of the masses - the proletariat, the workers class - that the party represents and aims at bringing to hegemony. ${ }^{20}$ In Gramsci, the political party performs the role the Prince plays in Machiavelli (see Chapter 7) - like the Prince, the political party must be properly educated for developing the skills necessary to grab and keep power. Indeed, this synthesis of Marxism and a distinctive interpretation of Machiavelli's thought is highly original, and one of the most interesting contributions to political thought provided by the Italian thinker. For Gramsci, rather than an individual, it is an organisation to play the key role in the struggle for political power that Machiavelli considered the essence of politics. And the war for political power may be won not necessarily in a decisive, one-off battle, but rather it may be conquered because the enemy - that is, for Gramsci, the other classes and the other parties representing those classes - get worn off, and this happens because the winning party imposes its values over society.

This vision of brutal, ruthless conflict for power might look horrific from an evaluative standpoint, but it contains important conceptual tools for analysis, at the interfaces and interstices between bureaucracy, political parties and other organised forms for conquering political power, that should not be overlooked by PA scholars. Let's see an illustrative example: Marxism was the ideology of the largest communist party in Western Europe, the Italian Communist Party, until at least the middle of the 1980s. Inspired by Gramsci's thought, and operating under conditions making the immediate conquest of political power via elections largely impracticable, the ruling elite of the Italian Communist Party pursued a strategy of shaping the values of civil society. A key target became the education of the younger generations, which in Italy occurred mostly in the public school system. Soon after the cooling of political tensions in the aftermaths of WWII, when it became clear that Italy would stay in the Western camp, the public education apparatus became one of the main targets of the Italian Communist Party. The key link in the transmission chain was identified in the production of school texts and handbooks, and hence in the role performed by the intellectuals that write them (and to some extent the publishers who distribute them, but as these were driven mainly by commercial logics, they were considered easier to steer). The indoctrination of school teachers was part of the process of shaping, in the long term, the values of the successive generations of Italians, educated (but in Gramsci's perspective the most appropriate term is 'indoctrinated') in the values of the working class 
(as interpreted by the party). By changing the values of society as a whole, over a number of decades getting to the office of government for the Italian Communist Party would then have been the almost automatic resultant of such a process.

As known, the takeover by the Italian Communist Party never happened, and so the result of this 'social experiment' cannot be observed. To make a long story short, this happened because the Communist ideology inspired by the 'Soviet beacon' (Gramsci was a fervent admirer of the soviet regime) at first tottered and then faltered and collapsed when the Berlin wall fell, bringing down with it the very Italian Communist Party, which changed name and nature over the subsequent decades. (The story should be completed by also noticing that the other parties did not stand still: the Christian Democratic Party notably exploited its position of office-holding by wielding an influence on the functioning of the education administrative apparatus - recruitment, career progression, and the like: often micro-managed by political appointees, see Cassese, 1993; Ongaro, 2009 - a move also aimed at counteracting the influence of the Communist Party on the Italian school system. It is in fact instructive to note that, although Italy generally had coalition governments, the post of minister for education was always held by an exponent of the Christian Democratic Party over the entire period 1948-92, that is, since the collapse of the Christian Democratic Party in the early 1990s.) But there are in Gramsci's thought a number of conceptual tools - like the emphasis on the significance of changing publicly held perceptions by infusing the national culture with the values of one's own party; or the analyses of the dynamics whereby political parties, especially the best equipped ones for grabbing power, strive to capture segments of the public sector in order to advance the party political agenda by manipulating the administrative apparatus - that should be part and parcel of the toolkit of PA scholars. We discuss this perspective of inquiry into public governance and administration issues in more detail in Chapter 4.

We can now complete this tour of post-Hegelian philosophy by turning to the critiques of Hegel's philosophy stemming from different standpoints than the Marxian, always keeping in mind that contemporary philosophy is in a number of respects the product of the reaction to Hegel's system. The Copernican revolution in philosophy brought about by Descartes, Kant and Hegel gave the subject a sort of absolute centrality in ontology: with it, prominence was acquired by another key property of the (human) subject: will and willpower. An original interpretation along this line is provided by the philosopher Arthur Schopenhauer. For Schopenhauer, our very body, and notably the muscles through which we exercise our will and which get resisted by the forces that oppose us, reveal that in essence we are willpower. Since willpower is conflict and tearing, life is in essence pain. ${ }^{21}$ Liberation from pain can only occur by means of the abandonment (transcending) of will towards the non-will, for 
which the Latin language has a specific word, noluntas, the negation of the voluntas (willpower). The abandonment of will, the giving up of any act of will, occurs through art and, ultimately, religion: religious ascesis through unconditional love (charitas or agape) can free humankind. The underlying philosophical conception is that it is an act of will, rather than cognition, to establish the world - or more precisely its representation: for Schopenhauer the world is representation - and this is an implication of the centrality given to the subject in the ontology of modern philosophy. Schopenhauer interprets the world as a representation of the subject, on which we strive to exert our will: the only possibility to discover the intimate nature of what we are is through willpower, and our only possibility to liberate ourselves is through giving it up.

This might appear quite abstract philosophical speculation, but this philosophical conception may be linked in ways closer than one might deem to social constructivist approaches (Berger and Luckmann, 1966). If reality is socially constructed, then not only cognitive capabilities, but also the intertwining of acts of will provide the building materials. The main point of difference between most of the contemporary social constructivist debate and Schopenhauer is the direction undertaken: rather than taking the route of individuals negotiating among themselves a shared narrative of good governance as means to making sense of a socially constructed reality and somehow bettering it, which is the way towards betterment that is referred to in some social constructivist approaches (see Abel and Sementelli, 2004, in particular for a highly elaborated presentation of this argument in the field of public governance; this point is widely discussed in Chapter 4), Schopenhauer suggests to simply abandon this representation, that is, to abandon the world altogether. Admittedly, in Schopenhauer's approach inspired by a religious afflatus there is very limited scope for public administration and public services: at most, they should act as enablers of artistic and religious life, which ultimately leads to salvation in Schopenhauer's perspective. Schopenhauer has been an influential philosopher and, although his legacy does not include a school proper (there are no 'Schopenauerians'), his bequest lingered and affected subsequent philosophical elaboration, and notably (we deem) social constructivist approaches.

The road of putting willpower at the centre was pursued to the extreme, and to utterly surprising consequences, by another German philosopher, Friedrich Nietzsche. He famously proclaimed that 'God is dead' and the world dances on chaos, and advocated a sort of return to the world of the 4th century BC Athens - that is, before Socrates and before Christendom, who for him corrupted mankind. Nietzsche's thought is imbued with soteriological elements, albeit fiercely adversarial of the Christian faith. Indeed, most of his philosophy is an attempt to 'make sense' of living in a world without God and exploring paths to cope with its consequences. The path to salvation lies in the 
acceptance of the tragic dimension of life (as fathomed by the masterpieces of Greek tragedy) and the pursuit of the spirit of Dionysus, the deity that in Greek mythology is associated with grape harvest and wine as well as with acting and drama, and 'what wine and acting on stage have in common is that they allow a person to set aside temporarily his or her ordinary, everyday identity and so the worship of Dionysus is characterized by a momentary suspension of the roles that society imposes on individuals' (Sansone, 2009, p. 140). What is possibly suggested by Nietzsche with the advocacy of a return to the spirit of Dionysus consists of setting aside the roles imposed by a society fraught with 'Christian values' and, through ritual madness, achieving a different self by fully embracing life. What is advocated is a pure acceptance of mankind as it is, attained by getting rid of revealed religion, of piety and mercy, and of the weak amongst human beings. One of the many provocative claims of Nietzsche is that during Renaissance the Borgia pope (notorious for his far from irreprehensible behaviours, and at the same time extraordinarily active in making of Rome even more than it already was the concentrate of artistic masterpieces we all admire) almost succeeded in getting rid of Christianity 'from within' and re-affirming the spirit of Dionysus at the very heart of the papacy. But his near achievement was - notices ironically Nietzsche's with his abrasive satire - thwarted by Luther, whose predication (as known, it formed and forms the basis of Christian reformed churches) re-instated Christendom for five more centuries. In sum, making a very long story short, for Nietzsche the pursuit of the spirit of Dionysus would bring about the so-called super-human or 'beyond human', a new creature (new in the existential sense, not in the biological sense) that would establish its own values rather than being subdued by the values of revealed religions.

It may at this point be noticed that a risk of drifting towards the irrational and the dominance of capricious, arbitrary will and the irrational over the rule of reason (and at times also over reasonableness) somehow lurks in any philosophy where both rationality and the subject are treated as 'weak'. These approaches are undoubtedly also a produce of the reaction to the absolute, omnipresent reason of Hegel. However, we would argue that extolling the irrational and willpower to the detriment of rationality (like the critical reason of the Enlightenment and Kant) also brings with it a high dose of risk of sliding down the path of the dominance of the capricious and the arbitrary will. ${ }^{22}$

Finally, Nietzsche also brought another element of the Hegelian system to its extreme: for Hegel (borrowing from Spinoza), the key category of being is that of necessity: all that is, necessarily is. This notion has been taken up by Nietzsche (in particular in the work Zarathustra) to the point of re-proposing the theory (already present in ancient Greek philosophy) of the eternal recurrence of the same: because everything obeys to the law of absolute necessity, every event will repeat itself indefinitely. This is meant literally: the same 
person will be re-born infinitely and will re-do the same things in the same circumstances. We would argue, however, that the ultimate thrust of this claim is not proposing a new cosmology, but rather it is undertaking a way to make sense of life: it is ultimately a way to find salvation (in the spirit of much of Nietzsche's work, which is about finding a way to make sense of a world without God: how to cope with the abysmal challenges posed by the consequences of living in a world in which 'God is dead'). The only choice, for Nietzsche, is to accept this eternal repetition willingly, to embrace our destiny of the 'here and now' being the only reality, although this gesture too will have already followed an infinite number of cycles beforehand. ${ }^{23}$

Nietzsche in a sense showed the contradictions in bringing to the extreme the absoluteness of the ontological category of necessity. It is the critique of the category of necessity as the only category of being (to the detriment of the category of possibility) that represented a key contribution to the dissolution of the Hegelian system brought about by the Danish philosopher Soren Kierkegaard. His thought was extremely influential on the philosophical movement of existentialism, which we examine later and which has had a distinctive influence on PA.

Implications for PA/Relevance for Philosophy for PA: Marxism and the thought of Gramsci continue to provide a range of conceptual tools and guiding ideas for researchers and practitioners alike in the political realm; for PA scholars specifically, it brings to the attention the centrality of the notion of power, a key trait of any political system which may be problematic to operationalise (March, 1999), and it has surely been overlooked by PA scholars, yet retains a key role for any deeper understanding of the dynamics of administrative systems.

We have also briefly hinted to how the Copernican revolution in philosophy brought about by Descartes, Kant and Hegel, which has given the subject a sort of absolute centrality in ontology, re-interpreted through the lenses of the subsequent 'crisis' (crumbling) of the 'strong' subject wrought out by these philosophers has paved the way for forms of subjectivism, relativism and (radical) constructivism that constitute an important part of contemporary social sciences, and a relatively small but quite vocal stream in PA (which we discuss widely in Chapter 6).

\section{HISTORICISM, THE SCIENCES OF THE SPIRIT AND THE PLACE OF VALUES IN THE SOCIAL SCIENCES, WEBER}

We can now go back to the main track of German historicism, stemming (or at least heavily affected) by Hegel's inheritance, where we encounter a number of key figures whose studies have provided major conceptual tools to the 
social sciences, and to PA specifically, notably Wilhelm Dilthey and Wilhelm Windelband. We owe to Wilhelm Dilthey (1833-1911; see a collection of selected writings in Dilthey, 1976) the notion of the 'sciences of the spirit' as distinguished from the natural sciences, that were at the time (19th century) developing at astonishing speed and apparently establishing a paradigm for the progress of human knowledge in general (an idea elaborated by the philosophical strand of positivism, to which we turn later). The sciences of the spirit are characterised by the fact that what they study are expressions of human life (in German, Erleben), objectivations of the spirit in the form, typically, of institutions (churches, states, religious or cultural-philosophical movements, and the like). When studying these objectivisations of the spirit (erlebnisse), the investigator, that is, the subject of the process of knowing, who is him/ herself a human being, is in a sense identical with the object of the process of knowing, which is the life historically lived by other humans who by means of their collective action effected historical events (the spirit in action). For example, when a scholar studies Luther and the Reformation, and then the councils and the Catholic Counter-Reformation, s/he is in a sense re-living those events, partaking of them, and finally and ultimately seeing the world in a different way by means of having gone through those events by having re-lived them through the study s/he has pursued.

It is in this fundamental sense that the sciences of the spirit are radically different from the natural sciences. They are inherently historical (different from the natural sciences that are a-historical), and by being the investigator a historical being him/herself, as is the object investigated, the kind of knowledge and understanding that can be gained in the sciences of the spirit is qualitatively different from the natural sciences. When studying the development of administrative capacity at the federal level in the US at the turn between the 19th and the 20th century (as is done in the excellent work by Skowronek, 1982), or the forming of bureaucratic autonomy in American federal agencies (Carpenter, 2001) or the parallel developments of public services in sectors like health, education and policing in Belgium and England since WWII (Pollitt and Bouckaert, 2009), the investigators (and we as readers) are in effect re-living experiences historically lived by public servants and changing ourselves and our view of the world through this experience. A key message for the discipline of PA, which partakes with the other social sciences the nature of science of the spirit, is that there is inherently and constitutively more than detached data collection and analysis or experimentation along the road of achieving an understanding of public institutions and their inner workings.

A genial precursor of philosophical historicism is the Neapolitan philosopher Gianbattista Vico (1668-1744). One of the first philosophers of history, he may be considered a forerunner in many areas of the social sciences. A crucial contribution by Vico, which in many respects anticipates and 
informs Dilthey's notion of the sciences of the spirit, is the so-called principle that 'truth is made'. Vico, abiding by a notion of knowledge as correspondence ('the conformity of the mind with God's order of things', see The First New Science, 1725 , p. xxiii), famously stated the verum factum principle, that is, that truth is made: what he means is that the social world is man-made, and for this reason it is also the part of the world that we can know better. Contrarily to what seems to be nowadays common wisdom, that is, that the natural sciences set the paradigmatic form of knowledge and the social sciences should follow the pattern, Vico states that we can attain full knowledge only of the human world, because it is the only world of which we can trace the causes (also by means of imagination, speculation, pure reasoning) for the very reason that it has ultimately been made (been laid down) by humans, throughout the history of civilisation. ${ }^{24}$

This philosophical stance is based on the rediscovery of an old maxim: 'Latinis "verum" et "factum" reciprocantur, seu, ut scholarum vulgus loquitur, convertuntur' - 'for the Latins "true" and "fact" are reciprocal, that is, as the common school people state, they may be swapped'. In other words, we may get to know, we may have knowledge of the causes only of what has been made by human beings, because we as human beings are the authors of it (in Latin, 'factum' is both 'fact' and the past participle of 'to make', so 'factum' here refers to something that both is a 'fact' and that has been 'made'). This entails that a different kind of knowledge is possible of man-made reality than what is attainable of natural (let alone divine) reality. In sum, for Vico the 'weak' sciences are the sciences of nature, and the 'hard' sciences are the sciences of human-made institutions, the social sciences. This is a big challenge for the many contemporary tendencies to put a premium on imitating and reproducing the protocols of knowledge generation and 'verification' of the natural sciences into the social sciences: a trend to which public administration is far from being immune. For Vico, those who pursue that direction are simply heading the wrong way.

Other anticipatory discoveries we owe to Vico include his reflections on the role of institutions. For Vico, institutions - although originally the creation of human activity - once established become powerful shapers of what is appropriate behaviour to which human courses of action have to comply, albeit with a larger or smaller leeway. This theoretical perspective might on face value look nothing new, given the wide currency nowadays enjoyed by the so-called 'logic of appropriateness' in explaining how decisions are made in organisations, as well as the diffusion of the strand of the theoretical perspective of normative neo-institutionalism (see March and Olsen, 1996; Peters, 1999/2005); however, about three centuries ago this way of looking at human-made institutions was profoundly innovative, and proved seminal (although the lineage to Vico's thought is not always fully acknowledged). Another genial conceptual 
novelty introduced by Vico are his reflections on the 'heterogenesis of the ends', that is, in more contemporary social science language, on the unanticipated consequences of purposive social action (Merton, 1936).

Wilhelm Windelband (1848-1915) coined another conceptual distinction, which proved seminal for later developments of the social sciences: it is the distinction between nomothetic and idiographic approaches to the investigation of social phenomena. In nomothetic approaches, the thrust is towards the 'discovery' of covering laws, of regularities in empirical phenomena so systematic to deserve being entrusted the status of a 'law'. Idiographic accounts, conversely, are thicker and deeper in terms of knowledge gained of the intrinsic case, the historical event or concatenated series of events (episode) about which an understanding is acquired by the investigator, and yet without the pretension to draw from this generalisations of sort; in fact, quite the opposite - it is the uniqueness of the happening of a certain episode that is the focus and the thrust in idiographic accounts. In later interpretations, the idea arose that so-called 'limited historical generalisations' can be drawn from idiographic accounts, notably when such accounts are treated through the comparative method (Ragin, 1987), but also from single (idiographic) case studies, in such ways that knowledge initially generated by means of an idiographic approach is capable of producing transferrable knowledge, that is, knowledge 'useful' also elsewhere in different circumstances. In the field of public administration and management, this approach has found fertile ground - traditional exemplars include Selznick (1956); examples of recent works include Barzelay (2001), Cejudo (2003), Gaetani (2003), Gallego (2003), Mele and Ongaro (2014), Ongaro (2006); and a recent advocacy of rediscovering idiographic accounts in PA is Terman (2011).

Another major figure is Heinrich Rickert (1863-1936), who introduced the distinction between factual judgements and evaluative - value-based - judgements. This notion would be widely elaborated by Max Weber (1864-1920), the giant of sociology, philosophy - and PA. Weber, a founder of the discipline of sociology and a central figure in PA, introduced a number of key concepts that still constitute the lynchpin around which some crucial discussions in the social sciences occur. First, the distinction between factual judgements and evaluative judgements, that is, judgements based on values and the consideration of what 'ought to' be alongside what currently is. Weber famously theorised that the selection on what is investigated with scientific method, out of the immensely wide complexity of reality whose entire exploration is beyond reach, occurs on the basis on the values of the investigator. A crucial difference between Rickert and Weber is that for the former the values transcend individual consciences and the 'ought to' is presupposed of any value selection made by one, specific social investigator. Weber seems instead to lean more towards an inherently subjective view of what values will actually 
guide social scientific investigation: the problems and the intellectual curiosity that guide social scientific investigation are more historically contextualised in Weber, and they ultimately lie in the individual investigator.

A second key notion distinguishing the human sciences and the social sciences from the natural sciences is that of interpretive approach: understanding (Verstehen) is required in the social sciences and the humanities, and knowing/explaining (Erklären) characterises the natural sciences.

Implications for PA/Relevance for Philosophy for PA: the authors examined in this section are central and directly relevant for PA thinking and they introduced key concepts on which PA, and the social sciences at large, widely rely, like the notion of the 'sciences of the spirit'; the conceptualisation of nomothetic and ideographic knowledge; the distinction between factual judgements and evaluative judgements. We have also noticed the significance of historicism and how conceptions of how history unfolds, and of conceptions of time, for PA studies (these are discussed in Chapter 4) Weber also introduced the method of the ideal typing, that we discuss later in Chapter 8. Also crucially for PA, Weber elaborated the so-called bureaucratic model, or - named after him - Weberian model of public administration, based on the notion of power as grounded in the primacy of the law, rather than in tradition or charisma. Also most famously, Weber outlined the conception of 'politics as vocation', and its implications for the role of charismatic political leadership, on one hand, and conceptions of citizenship and the underpinning notions of negative and positive freedom enjoyed by citizens, on the other hand. These crucial topics are not further discussed here because they have been widely covered in a deluge of other PA works (for an overview and review of the inheritance of Weber in Europe and the US, see Rosser, 2018). The treatment of Weber's thought ${ }^{25}$ here is disproportionately brief only because it is already so extensively discussed within the discipline of PA, and the thrust of this book is bringing to light contributions from wider philosophical streams than those already enjoying wide currency in the field of PA.

\section{POSITIVISM, CONVENTIONALISM, POPPER}

Positivism lies quite at the opposite of historicism, in terms of ontological and epistemological stances. Positivism is a philosophical movement that was born and grew rapidly in the 19th century and whose key tenets include a total, indeed fideistic, reliance on the primacy of 'scientific knowledge'. It is, in important respects, an offspring of empiricism, but with its distinctive twists. Scientific knowledge, patterned on the natural sciences that had been consolidating since the 17th century in Europe, is deemed to be the only form of knowledge. Notably, the method(s) of the natural sciences (summed up as 'verification' of theories by testing them against 'facts') is also considered 
applicable to the study of society: the method of the natural sciences is the model for the social sciences as well.

This total reliance on scientific knowledge is coupled with a very optimistic view of the benefits that can derive from progresses in such knowledge: scientific knowledge was considered by 19th century positivists as the key resource for addressing and ultimately solving all the problems that had historically afflicted mankind: progressivism and optimism are thus qualifying traits of positivism. In this perspective, the 'fact' is the only solid foundation of knowledge and indeed of the organisation of individual and associated life: idealism and spiritualism are rejected and dejected as 'metaphysical' (it is with positivism that the term 'metaphysic' acquires the negative connotation which is so widespread nowadays). Leading figures of positivism include Auguste Comte (1798-1857), Herbert Spencer (1820-1903) and Roberto Ardigò (1829-1920).

To better situate positivism in historical perspective, it should be noticed that a number of key tenets that can be found in positivism, like the primacy of the critical reasoning searching for 'facts' to unmask and dispel prejudices, were flags already flown by the Enlightenment and before by the protagonists of the scientific revolution in the 17th century. On the other hand, the factual scientific progresses that had been brought about during the 18th and 19th centuries and the material progresses engendered by the deployment of the effects of the Industrial Revolution that started in England in the 18th century and was spreading throughout Europe have surely inspired that optimistic 'positivistic' - view of human development that characterised 19th century Europe. European nations, although deploying an aggressive colonialism in Africa and Asia, were enjoying a historical and political context of limited warfare in Europe (with the exceptions of the Crimean and Franco-Prussian wars), and the worldwide dominance of Europe through colonialism in Africa and Asia was the breeding ground of a form of political-cultural dominance of the Western civilisation across the world. All these contextual factors might help explain the 'optimism' that pervaded the epoch, and its philosophical movements.

From an epistemological standpoint, one key tenet of positivism is the importance of induction for knowledge. This has to be situated in the frame of a harsh polemic towards the notion of the 'syllogism' (of Aristotelian origin and widely upheld during the medieval age) as the lynchpin of logic. John Stuart Mill developed a harsh critique of it: if the major premise is indemonstrable (e.g. all humans are mortal), then the minor premise and the derived consequence (Wellington is human, and hence Wellington is mortal) become wrong (Mill, 1843/2011). The critique is that it is only through inductive reasoning that we can achieve reliable knowledge (in the example, knowledge about the major premise of the reasoning: that all humans are mortal), and therefore the demonstration could occur only via empirical, factual testing 
(Wellington at that time was alive and well, and his mortality for Stuart Mill could not be proven via the major premise, as in syllogistic reasoning). This critique has opened as many problems as it has allegedly settled: although forms of inductive reasoning, like statistical inferential analyses, are everyday tools of the social scientist, problems about how to generalise from induction are still unresolved and continue to haunt logicians and social scientists. Mill also introduced the distinction between heteropathic and homopathic laws (Mill, 1843/2011), by contrasting two modes, the 'mechanical' and 'chemical' modes, in which causes may act conjointly. For Mill, the gist of the mechanical mode lies in the property that the total effect of several causes acting in concert is identical to what would have been the sum of effects of each of the causes acting alone: in mechanics, the vector of the forces is the sum of each of them (considering the direction and verse of each force in the space); this is the homopathic effects of each individual component of a system operating under homopathic laws: that is, the total effect is the sum of the effects produced individually by each part. The gist of the chemical mode, conversely, lies in the fact that the joint action of multiple causes is not the sum of the effects of each cause had they been acting individually, as shown by a chemical reaction, whose effects are not the sum of the effects engendered by each component in isolation; this is the heteropathic effect of each individual component of a system operating under heteropathic laws. This notion has paved the way for the elaboration of the notion of 'emergence' and of emergent properties, and the ensuing stream of thought called emergentism, discussed in Chapter 4 in relation to social ontology and its application to PA.

Positivism has a revival in the 20th century embodied in the so-called neo-positivism. A key promoter was the 'School of Vienna', led by such figures as Moritz Schlick (1882-1936) and Rudolf Carnap (1891-1970).

One major strand of critiques to positivism came from a movement known as conventionalism. Authors in this strand include Mach (1838-1916), Avenarius (1843-1896), Poincaré (1854-1912), Duhem (1861-1916) - although not all of them can be placed, at least not squarely, under the label of conventionalism. Mach developed a critique of the assumptions of absolute space, time and movement of Newtonian physics that paved the way to its crisis and, later on, the acceptance of the astonishing implications for the conception of space and time brought about by theory of relativity elaborated by Albert Einstein. He minted the conception of scientific knowledge as economy of thought: the more valuable a theory is, the more it covers a wide range of phenomena with explanations that are the simplest possible. The criterion of parsimony (already encountered in William of Ockham) that permeates current conceptions of what a 'good' theory is owes much to Mach. The key contribution by Mach, which constitutes the essence of conventionalism, is more revolutionary than the criterion of parsimony though: it is the claim that theories do not have, or 
do not necessarily need to have, an intrinsic validity in terms of detecting the causes; they are just functional relations 'that function' for predicting a range of phenomena; they are a 'fit for purpose', apt convention and hence the mint of the term 'conventionalism' to describe this philosophy of science. Like any convention, they may be replaced by another if it proves to be more suitable.

A key contribution by Avenarius is the notion that experience, in order to be an acceptable 'valid' source of knowledge, has to be made public through verbal assertion. This methodological assertion embodies both a critique and an assumption. The critique is to the very possibility of the experience of the interiority, in direct criticism of Descartes's methodological approach of the 'I think' and all the followers, a critique that he brought to the point of dissolving any psychological experience and reducing it to the purely biological element. The assumption is that for experience to be valid, it must undergo the requisite of being public: the publicity of the research process and the procedures for their replicability, which has become a widely held criterion in the natural and social sciences alike ('always conduct your research as if a fellow scientist were behind your shoulders observing all you are observing'), although in the social sciences this may be far from being totally unproblematic, let alone always feasible.

Poincare elaborated the notion of science as a rule for action. The starting point is the consideration that not all facts can be given heed, and hence it is the scientist to select what facts deserve being observed and studied - a statement that resonates in Weber's notion of values guiding the choice of phenomena to be observed and studied. In this perspective, 'valid' theories are those more productive of results in terms of being useful and 'handy' for studying phenomena - or just handy: so Euclid's geometry for Poincaré does not contain a higher degree of truth value than other geometries, but it is widely used because it is the most handy of geometries, at least for the problems of the common people. ${ }^{26}$ Implications (quite astounding on second thought) include that theories, contradictory amongst themselves, may co-exist in explaining different phenomena, or phenomena seen from different angles, like in theoretical physics where the theory of relativity and quantum theory co-exist, albeit being partly contradictory (but they are applied to different phenomena, the theory of relativity applies to the cosmic scale of the extremely big, quantum theory to nuclear and sub-nuclear particles and the extremely small ${ }^{27}$ ), or like the 'double nature' of light, described as a wave or as a sheaf of particles, depending on how it is observed.

Duhem developed a critique of the experimentum crucis conceived by Bacon (Chapter 2). He argued that any time a hypothesis is tested, what is tested is effectively a whole range of hypotheses, auxiliary to the one being tested, not just the one allegedly undergoing the crucial experiment. For this reason, it cannot be drawn from the result of the experiment that the alternative, oppo- 
site hypothesis is 'verified' (if the experiment leads to discard - falsify - the tested hypothesis). Karl Popper went further in this line of critique, arguing that it is also not possible to formulate only one alternative hypothesis to that which is tested: infinite alternative theories can always be produced, and hence no single experiment is capable of testing which one to retain and which to discard between two theories.

Concepts and notions worked out by conventionalism are now part and parcel of the toolkit of the natural and the social scientist alike, and public administrationists are no exception: it is hard in this respect to overestimate the influence of these ideas on contemporary scholarly research in the field (a simple browsing of books on the methodology of the social sciences, and the less numerous books dedicated to researching PA, points to this, e.g. van Thiel, 2013). It is equally impossible to overestimate the influence of Karl Popper on the philosophy of knowledge (Popper, 1934/1977).

Karl Popper made a major contribution to the epistemology of the sciences as well as to politics and liberal political thought. For reasons of brevity, here we only touch very briefly on one key contribution he made, namely the critique of induction and inductive knowledge that forms such an important part of both positivism and conventionalism, as we have seen. For Popper (making a very long story short), induction does not exist and it cannot ground any knowledge. Knowledge is always the product of the testing of a theory - not any theory, but those that are most parsimonious and capable of providing explanations of phenomena, provisionally valid if they successfully undergo the testing, until they get falsified, that is, until evidence can prove the theory wrong. The theory is not immediately entirely rejected: it may still serve the purpose of providing a partial explanation of some phenomena (Newtonian physics is still widely retained and employed for its capacity to explain most phenomena for the purposes of most branches of applied engineering; however, it is falsified when it comes to explaining phenomena in the very macro-scale of astrophysics or the very micro-scale of particle physics), but it will eventually be replaced by a more supple and apt theory, which will be held 'true' only insofar as, and until, it will be disproven by novel evidence and experiments: it is the so-called principle of falsification. But where do theories come from? For philosophers like Charles S. Peirce the observation of surprising facts may be a powerful source of conjectures and hence, ultimately, theory generation. Popper is more open to a multiplicity of paths towards theory formulation. The mind for Popper is not tabula rasa, a blank sheet or a blackboard on which, through induction, 'veritable' knowledge can be written through accumulation of experience, and false knowledge, that is, prejudices, should be wiped out with a board rubber. Popper does not criticise Peirce, for whom induction was just a source of opportunity for thinking of and elaborating a novel theory to then be tested, but rather Positivists, who claimed 
that accumulation of scientific knowledge could occur through pure induction. Knowledge for Popper always starts from expectations or 'hypotheses' that are already in our mind: they may derive from tradition, from philosophical speculation, and most often these expectations presuppose a metaphysics and derive from it. But, hypotheses must always pass through the sieve of empirical testing and experimentation. Only the hypotheses (and the sets of related hypotheses that constitute a theory) that provisionally pass empirical testing can be held as 'provisionally' true, until further testing will disprove them. For Popper, there is asymmetry between falsification and verification: thousands of controls cannot 'verify' a theory, cannot prove it is true. One disproval is enough to falsify a theory.

Popper's epistemology has been seminal for a huge debate about how scientific knowledge proceeds, and notably whether it proceeds only through theory-testing, or also through induction, of which there are different forms. No final word can of course be uttered on this gigantic problem of philosophy of knowledge. According to Popper's epistemology, scientific inquiry is seen as a competition between scientific paradigms: sets of core hypotheses, a sort of nucleus of assumptions which as such are never directly tested, but from which a range of hypotheses are derived and tested. To the extent they 'pass the test' of empirical falsification, they are provisionally held as true; and they are encompassed into wider and more sophisticated theories. However, often these sophisticated theories rely on a core of untested hypotheses. When one or more experiments lead to discard some of the consequences of such hypotheses, theories may be adapted or refined to encompass the disconfirming evidence. It may also happen that new evidence cannot be accommodated into pre-existing theories. This may lead to the old paradigm running into crisis and a new paradigm to arise and ultimately replace it - temporarily before it is also challenged by newer paradigms (which at times may represent the re-proposition of old and forgotten ideas). The philosopher Kuhn (1962/1996) is associated with the conceptualisation of scientific knowledge as proceeding through an alternation of periods of 'normal science' in which accumulation of knowledge (in the form of convergence, consistency, problem-solving capacity, see Riccucci, 2010) occurs within one dominant paradigm, and periods of paradigmatic revolution in which a new paradigm replaces the old one in the given discipline (Reale and Antiseri, 1988). It is questionable (and questioned in heated debates), however, whether in the field of PA it is possible to speak of 'dominant paradigm' and 'accumulation of knowledge'. It seems more appropriate to speak of a plurality, if not a babel, of co-existing paradigms (Riccucci, 2010).

Popper's epistemology has raised huge questions. Is this the whole story? Does knowledge progress only through theory-testing, and then conceptual tools like reasoning by analogy have to be dumped and ruled out of the array 
of possibilities available to the investigator? The story might be more nuanced - and fascinating. First, is 'reasoning by analogy' to be ruled out? ${ }^{28}$ What is meant by reasoning by analogy is (in a very synthetic way) a process whereby knowledge of some other entity (the targeted object of knowledge) is attained by means of the knowledge of one entity which partakes with the target entity certain features. It also generally means the more 'strictly' metaphysical assertion that the knowledge of entities participating of being is a way to reach an imperfect knowledge of being as such (and it forms a branch of theology relating to what can be known of God through knowledge of entities: see in Chapter 2 the philosophy of Aquinas). These questions are more contemporary than usually thought of, although in contemporary 'scientific' journals they are usually discussed in different guises. When asked the question 'what is a theory and how does theory-construction proceed?', contemporary social scientist and organisation theorist Karl Weick provocatively answered that theory construction would be about standard theory validation (whereby a hypothesis or set of hypotheses are tested by empirical means) if such a thing existed at all: However, 'the reason it does not is that validation is not the key task of social science. It might be if we could do it, but we can't' (Weick, 1989, p. 524). Rather, he depicted theory validation or verification as the resonating of a theory to the experience of other experts; and what is the ultimate source of the 'experience' of other experts? It is the experiential knowledge of other things, with which they compare the claims of the proposed theory; ultimately, we would argue this is a form of reasoning by analogy re-proposed, albeit in partly different guises than traditional metaphysics, to the attention of contemporary social scientists as the way to theory construction. Weick (1989) went further to advocate the usefulness of metaphors in theorising in organisation studies. The conclusion we can draw is that reasoning by analogy may enjoy much broader currency in contemporary social sciences than generally considered.

This line of argument is not meant to dismiss the huge influence of Popper on the philosophy of science. Popper has been a hugely influential philosopher and scholar. A highly significant approach in contemporary social sciences, referred to as 'critical realism' and propounded by prominent scholars like Pawson (2006; Pawson and Tilley, 1997), is significantly indebted to Popper's philosophy. It is instead meant to remind of other, alternative paths of inquiry that have roots in century-old traditions of philosophising and that may continue to contribute to knowledge.

Implications for PA/Relevance for Philosophy for PA: concepts elaborated by these philosophers are crucial for the epistemology of social sciences in general, and notably for PA (it may also be noticed that positivism, and its intellectual heirs, have shaped a major intellectual tradition in PA, which is widely discussed alongside other traditions in Chapter 9). We will return to 
Popper in the next chapter and in Chapter 5 (where we also discuss the political philosophy of the 'open society' and its 'enemies') as well as in Chapter 6 and 8 .

\section{PHENOMENOLOGY}

Phenomenology is associated with the work of Edmund Husserl (1859-1938), who is considered the founding father of this movement, and philosophers like Max Scheler, Nicolai Hartmann, Rudolf Otto, Edith Stein, amongst many others. Alongside its distinctive contribution, phenomenology also had a major influence in the development of another philosophical movement of the 20th century, namely existentialism, to which we turn at the end of this section.

Crucial for the development of phenomenology are the works of Bernhard Bolzano and Franz Brentano. Bolzano is a logician and mathematician who vehemently opposed the claims of psychologism about the origins of mathematical and logical concepts lying in psychological processes; instead, he claimed that the truth value of a proposition lies in itself, that verity is given in each and any valid proposition, irrespective of whether it is expressed or not, or whether it is thought or not (thus in certain respects returning to claims of classical metaphysics). Franz Brentano highlighted the intentionality of psychic phenomena, which are characterised by the fact they are always referred to as something that is other than the psychic phenomenon itself (when a subject endowed with psychic activity thinks or feels, the thinking or feeling is inherently intended towards 'otherness': in psychic processes of representation, the object is purely 'present' in front of the thinking subject; in psychic processes of judgement, the object is affirmed or denied; in psychic processes of sentiment, the object is, at the most basic level, loved or hated). This also has roots in classical philosophy: in the Scholastics, intention refers to the concept in its inherent characteristic of indicating something diverse from itself (tending to something, stretching out to something other than itself). Brentano was a mentor of Edmund Husserl.

The starting point of phenomenology is the possibility of knowing the essences (Husserl, 1913, English transl.); it is a movement aiming at 'going back to the essences' of things, beyond psychologism - whereby concepts are considered to be the product of psychological processes - as well as beyond positivism - whereby knowing is observing facts. For phenomenology, facts are not the ultimate reality; instead they are doors open to the essences - phenomena are not the limits of knowledge (like in Kant), but the door through which the things in themselves may become known. When conscience catches a fact 'here and now', it always gets an essence, for example this colour is a particular instance of the essence 'colour', this sound is a specific instance of the essence 'sound', this triangle is an instantiation of the essence 'triangle', 
and so on; and although the fact is contingent (this sound might also not there be) and facts are varied (the sound of a piano, a violin, a trombone, etc.), in each and every experience of a sound we may recognise an essence, the common essence of a(ny) 'sound'. This is a point of difference with empiricism: knowledge does not occur by abstracting common features by means of comparison of similar observations; it is first and foremost knowledge by means of intuition of the essence of things (even 'similarity', used in empiricism to compare 'similar' observations - is already an essence we know, before we use it: we use the essence of similarity in order to compare).

The method for knowing essences lies in the process of 'epoché' (from the Greek $\dot{\pi} \pi \sigma \chi \dot{\eta}$, a term derived from the philosophical movement of scepticism), which is intended as the suspension of judgement; that is, the bracketing of judgement in order to 'enable' things to manifest themselves to the conscience (this process is technically known as 'phenomenological reduction'). It should be noticed here that the English term 'epoch' has the same origin: it also refers to a process of suspension to let the distinctive trait of one historical period emerge and qualify that period, which thus becomes a distinctive 'epoch' of history. The knowledge of essences is articulated into a formal ontology, the general knowledge of essences, and regional ontologies, the knowledge of essences pertaining to certain areas, like nature, morality, society or religion. Research in these areas has led to philosophical investigations of moral values (like in Scheler's work), or of the religious experience of the sacred (as in Otto's work).

There is - we may say - much of Aristotle in the knowability of things through phenomena. However, there is also the modern philosophy of the Cartesian 'methodological doubt' and the centrality of the subject. For Aristotle, like for the entire Greek civilisation, the subject, notably the human subject, was ultimately a part of the universe, without any special role to play in Being and the knowing of Being. But for modern philosophy after Descartes and Kant, the subject is a starting point. Also in Husserl, what cannot be the object of phenomenological reduction is the conscience, or subjectivity, which is labelled the 'phenomenological residue' and which cannot be bracketed: the world, according to Husserl, is constituted by the conscience. The question is whether 'constituted' means that it is established by the subject, or just revealed and given meaning by the subject. It is at this juncture that we find the distinction between idealist phenomenology and realist phenomenology. Idealist phenomenology, to which Husserl adhered in the last part of his life, stresses the subject as establishing the world, whilst realist phenomenology sees the subject as the ultimate recipient of the revealing of the world and the giver of meaning to it, but the world ultimately 'pre-exists' the subject.

Both strands, however, share an opposition to positivism: the observation and measurement of 'facts' detached from the essences that may be intuited 
does not lead to knowledge, or at least does not lead to profound knowledge: it may at most scan the surface of things. (Neo-)Positivist philosophers have retorted that the assumption that inside 'facts' it is always possible to capture essences simply adds a 'morass' of (what Neo-Positivists argue to be) 'interpretations' and vague concepts that hinder rather than advance clarity of knowledge. Phenomenologists in turn reply that the investigation of essences is conducive to a deeper and more meaningful knowledge of reality than the measuring and labelling of things that characterises the positivistic stance.

On a concluding note, it should be clarified what, in our view, phenomenology is not: it is not social constructivism/constructionism in its idealist or in its realist variant. First, it is not 'social': Husserl placed the absolute subject at the centre, rather than inter-subjectivity which is centre stage in social constructivism (inter-subjectivity is a notion that originally figured in Hegel's philosophy). Nor is reality 'constructed' in a phenomenological perspective: the world may be 'constituted' by the subject (in the idealist perspective, see earlier); but things can be known in their essence rather than being constructs - knowledge is penetration of essences, getting to know essences by means of phenomena as open doors. If these qualifications of phenomenology are appropriate, then some applications of phenomenology to PA (see Waugh and Waugh, 2006) appear ungrounded. We discuss this claim when applying phenomenology to PA.

Implications for PA/Relevance for Philosophy for PA: we discuss application of phenomenology to PA - as part of a larger approach to inquiring and investigating society, for example including moral values, religious values - in Chapter 6.

\section{EXISTENTIALISM}

Existentialism is, like phenomenology, a philosophical movement that occupies a major place in 20th-century philosophy. It is associated with philosophers like Martin Heidegger and Karl Jaspers in Germany, Merleau-Ponty and Jean-Paul Sartre (1938, 1943) in France, and Nicola Abbagnano (1946/1963) in Italy. In this very concise summary we will refer mainly to Heidegger, first to his masterpiece Being and Time (1927), and then to the works after the so-called 'turn' in Heidegger's thought, namely all the subsequent works.

The entry point for understanding existentialism is to describe what existential analytics is about: the very word 'existentialism' derives from the root word of 'to exist', that is, ex-sistere: 'to stay projected towards the outside'. For existentialists, the experience of existence, which is ultimately unique and irreducible to anything else, is the starting point of philosophising. But the experience of existence requires being analysed with its proper method, which is referred to as 'existential analytics'. Key experiences (in the plural) of exist- 
ence become centre stage for the understanding of Being: the human being is in fact that special entity (the root word for entity in Latin means 'what that is', what has the property of being) that interrogates itself on the sense of Being. It is, in this sense, the door open to being (existentialism and phenomenology both look for a door open towards Being, but while phenomenology searches for it in phenomena, existentialism heads towards the experience of existing in itself as the pathway towards Being). In this respect, existentialism shares with modern philosophy the starting point of the subject interrogating itself and the world, although the emphasis in existentialism is on the 'lived experience' rather than the pure act of thinking by the thinking subject, as in Descartes. ${ }^{29}$

The distinctive trait of the human being as 'existence' in its very nature of being a 'possibility' is brought centre stage: ${ }^{30}$ the existence is never a simple 'being present', the existence is never 'an object amongst other objects'; it is always constitutively a projection, the concrete possibility of becoming something but also something else (and in this outright rejection of the category of necessity as the sole category of being it is evident the lineage of existentialism to the Danish philosopher Kierkegaard, a harsh critic of Hegel's philosophical system). Key traits of existence are the 'being-in-the-world' (in the original German: in-der-Welt-sein), the 'being-with-the-others' and the 'caring'. The world is not originally something to contemplate, but instead it is a set of possibilities and instruments for each human being to use in order to accomplish its own existential project. For this reason, for Heidegger the problem of whether the world exists and how its existence can be demonstrated (one may consider here both the Cartesian methodological doubt or the scepticism of the empiricist David Hume) is pure non-sense: there cannot be a subject without a world, nor is there an 'I' without the others (for Heidegger, like for Husserl, the others are not inferred as other 'I' alongside one's own 'I': they are originally given - the other 'Is' (the plural of 'I') are originally and constitutively given to the individual 'I'). If the existence is originally in the world as a set of possibilities, then existence expresses itself in 'caring', in taking care of the world. Existence can also be authentic or inauthentic: it is inauthentic, or anonymous, when it is dominated by chatter and by fatuous curiosity, when, ultimately, the existence renounces its distinctive trait of choosing what to become and lets itself be driven by impersonality, for example by maxims like 'everybody does it', 'everybody says it'.

This constitutive dimension of existence has been picked up by scholars of PA (see Waugh, 2006), especially during the 1970s, for depicting the distinctive figure of the 'existentialist public administrator' who 'cares' and 'takes responsibility' for the general public rather than accepting impersonality as the key trait of bureaucratic behaviour. It is the profiling of the so-called 'pro-active public administrator', the administrator for whom 'caring' is a central notion, and possibility rather than necessity is the dominant onto- 
logical category. It is a philosophy of responsibility and decision in public administration different and possibly at odds with the Weberian conception - or at least at strain with certain interpretations of the Weberian bureaucracy. We return to this perspective in Chapter 4.

By developing his existential analytics, Heidegger (like Jaspers) arrives at the constitutive dimension of existence - which is its death. Death is here conceived as the possibility that all other existential possibilities become impossible. Death is the possibility of the impossibility of carrying out any project, that is, of accomplishing one's own existence. This is the 'being-for-the death' that characterises existence, and which is ultimately a totally individual experience - nobody can take upon her/himself the dying of somebody else. Put simply: each of us has to face her/his own death, and 'death' is ultimately, always, $m y$ death. This means that in order to live an authentic existence each of us has to 'live-for-death', not in the sense of effecting it through suicide (this is not at all Heidegger's thought), but rather in the sense of living every moment of the existence in the consciousness of death. This consciousness is not an intellectual act, but is embodied in the experience of anguish. Anguish is the sentiment of nothingness, of non-being. It is the consciousness of ultimate annihilation that characterises each and every existence. It is in this sense distinguished from fear, which is the dread of some other entity - we fear a threat posed by an entity, but we feel anguish in front of the non-Being as such.

Existentialist reflection on the nature of the being-for-the-death led Heidegger to what he referred to as 'the turn' in his philosophical reflection. The turn is a shift from the centrality of the individual existence and the analysis of it (the existential analytics developed in Time and Being, probably the single book that most shaped existentialism as a philosophical movement) to the orientation towards Being 'in itself'. The turn consists in the rediscovery of the process of 'unveiling' of Being or, to use Heidegger's favourite expression, the non-hiding of Being: the keyword here is the Greek ' $\alpha \lambda \eta^{\prime} \theta \varepsilon 1 \alpha$ ' (aleteia), and the non-hiding of Being is a historical process, but yet revealing the transcendence of Being. Heidegger carried out a radical critique of all metaphysics, from Plato and Aristotle to Hegel and even Nietzsche, as having led astray philosophical thought. Starting from Plato's world of ideas, he considered it as the point of departure from the main road tracked by the pre-Socratic philosophers: the very notion of idea - whose root word in Greek is 'to see' - entailed a dominating role by the subject who sees, and hence first sowed the seed of that 'willing of possession', denounced by Nietzsche, that has dominated all (Western) philosophical thought throughout two-and-a-half millennia, impeding philosophy to become the venue of the unveiling of Being, rather hindering it. Of central significance are his reflections on the question concerning 'modern' technology (and its difference to the techne, or technê from the ancient Greek language, of the Greeks), where he suggests that 
instrumental understandings of technology are shallow, remain to the surface whilst something deeper happens when technology affects the relationship between humankind and Being. One main road towards the rediscovery of the unveiling of Being is represented by the arts, to which Heidegger - a man with an incredibly vast culture spanning the divinities, the humanities and the arts - assigns a special power in enabling an understanding that philosophical reasoning has lost (he elaborated a distinctive aesthetics, or philosophy of the beauty, in his work Hölderlin and the Essence of Poetry; Heidegger, 1981/2000). His philosophy gives both a special and a specific significance to the artwork: each artwork is a 'whole world' where the non-hiding of Being occurs, and hence contemplating a masterpiece is a source of understanding. If art is revelatory beyond what philosophy and the sciences can shed light upon, then the contemplation and appropriate interpretation (exegesis, hermeneutics) of the artwork is a way for gaining distinctive and otherwise unreachable insights, and the study and the interpretation of artistic masterpieces can provide a source of insights into reality.

This applies to all 'regions of being'. In this sense, it can be argued that it also applies to public governance and administration. We claim that this is also the case with the masterpieces that have addressed the world of governing, of public governance and of public administration - and we illustrate this through the discussion of Ambrogio Lorenzetti's famous masterpiece The Good Government, which we examine in Chapter 6, based on consolidated scholarly work on the theme.

There is another key notion in Heidegger's analytical apparatus that deserves mentioning - also for its implications for PA. Heidegger carried out a radical critique of the notion of 'time' that is used in the sciences as they consolidated since the 17th century. In Being and Time, Heidegger develops an analytics of time that takes the move from the notion of 'ecstasy', in the etymological meaning of 'staying, or lying, outside (of oneself)'. For Heidegger the fundamental dimension of time is the future: existing means projecting; the primary meaning of any (human) existence lies in its projection to build her/his own future in the world through the activity of 'caring'. But ecstasy applies to all dimensions of time: if the future is lying outside of oneself towards what will be, the past is staying outside of oneself towards a situation of fact to accept it (something which is past cannot be changed, although it can be interpreted and accepted); the present, finally, is lying outside of oneself to stay next to the things. There are two ways of 'living the time': authentic and inauthentic. Authentic is when existence as the being-for-the death lives by assuming death (one's own death) as a qualifying trait of existence: this way one lives without being overcome by the mundane things of life. The authentic present becomes the living of the present as 'instant', in which the human being decides her/ his own destiny, and the authentic past is when the existence accepts and 
re-lives the possibilities that tradition has given us. A key implication of this conception of time is that the time used by the natural sciences and - in most cases - the social sciences (that is, the time that can be dated and measured) is inauthentic time: it is not the time of life, nor is it the time in which we may gain any authentic understanding of being. This is a fatal blow for most of the 'knowledge' that is generated through 'scientific' procedures. The challenge applies, perhaps even with a special intensity, to the scholarly study of political communities and the ways in which citizens' lives unfold in them: is the 'real' time of lives of the citizens unfolding in their communities taken into account in studies of PA - even those that adopt qualitative methods, longitudinal perspectives and forms of direct, participant observation?

Implications for PA/Relevance for Philosophy for PA: existentialism has inspired and elicited a strand of studies in PA, which has also led to minting the term, and profiling the figure, of the existentialist public administrator, widely discussed in Chapter 4. Separately, we also return on Heidegger's notion of time and its implications for PA also in Chapter 4.

\section{STRUCTURALISM}

Quite at the opposite of existentialism, the starting point of structuralism are - as the name conveys - the deeper structures that, according to this philosophical movement, explain society and humankind. The human subject or 'I', whose utmost prominence we have encountered in modern philosophy since Descartes, is dethroned by structuralism to give way to the inner structures into which the 'I' dissolves.

One of the founding fathers of structuralism, Claude Lévi-Strauss, in exile in Brazil during the 1940s while war was raging in Europe, carried out a famous study on the populations of the Amazon and, based on findings from his study, claimed to have identified certain elementary structures of kinship that appear to characterise that distant society - distant from both Eastern and Western civilisations (Lévi-Strauss, 1949). His contention was that his study shed light on 'laws' that characterise societies across time and space (famously, he studied the prohibition of incest). Analogously, Michel Foucault, a very prolific and highly influential author, devoted his attention in a range of renowned works to exploring how epistemic structures perform as key drivers of historical processes. The work of these and other philosophers aims at uncovering the deeper structures ${ }^{31}$ that govern human societies.

Structures are a key category of analysis in both the natural and social sciences in order to explain phenomena ('features that, prima facie, seem likely to affect the process of public management reform [..] include structural, cultural and functional elements', to stick to the subject matter of our book and mention a much-cited book in the field of public management: Pollitt and 
Bouckaert 2004, p. 40). The findings of the previously mentioned scholarly works about deeper structures influencing society, either its constitutive family bonds like in Lévi-Strauss's work, or the transition between epochs on which Foucault's study sheds light, might be accommodated quite laically within a variety of philosophical perspectives. But what characterises structuralism is the suffix 'ism' at the end, something which we might translate (from ancient Greek) as 'all is' or 'the entirety of being is': so structuralism as a philosophy asserts that structures explain everything. This is the philosophical meaning of structure: deeper, unconscious structures are the ultimate explanation of reality (or that part of reality which is within the reach of some form of human knowledge). Structuralism is thus an attitude that pretends to explain the human and the social in terms of deeper structural influence in which the human subject, the 'I', the conscience and the self-conscience are ultimately dissolved. This is also the problem with structuralism: structures are part and parcel of the explanation of human societies, but why the hidden dynamics and why should the hidden 'reasons' of deeper structures be the reality, the totality of being? And what criterion of truth enables the identification and distinction of the 'true' ultimate structures of being? In fact, if we follow the central claim of structuralism, we are led to a contradiction: human rationality and conscience should at the same time be the judge about the truth value of the claim that reality ultimately consists of deeper structures whilst they themselves dissolve into these structures; human conscience is at the same time claimed not to exist other than dissolved into structures that transcend it, and yet at the same time this assertion can only be grounded by a rational conscience stating it. It is these questions that pose serious limits to the pretensions of structuralism to qualify as an ontology. However, the findings of the manifold studies in this stream are evidently important contributions to the understanding of social dynamics, and by themselves can quite easily be accommodated into different philosophical viewpoints and accepted within a wide range of perspectives. The influence of structuralism on the social sciences is undoubted, and there is still much that can be borrowed from it, notably in the study of public governance, by plucking into the toolkit of structuralist thinkers. Moreover, a structuralist perspective may represent a critical alternative framework to other approaches, that when combined may shed additional light on human and social phenomena (one might contrast the structuralist anthropology à la Claude Lévi-Strauss with cultural anthropology and the notion of human culture as an irreducible act of creativity à la Tylor, 1920; Kroeber, 1952, in order to see how fruitful the combination of different perspectives may be in shedding light on social phenomena).

Implications for PA/Relevance for Philosophy for PA: structuralism and notably the potential multiple applications of the notion of social structure to the advancement of PA studies is discussed in Chapter 4, where also and 
more broadly the topic of how PA can tap from, and benefit of, the findings of social ontology is developed. Social ontology may be seen as a branch of ontology, a regional ontology whose focus is on the nature and foundations of social entities and their constituent or essential properties. Its lineage is in many respects in structuralism, as well as in Vico's thought, and we will return to these philosophies when discussing in Chapter 4 the implications of social ontology for PA studies.

\section{OTHER KEY 20TH-CENTURY STRANDS: PRAGMATISM, PROCESS PHILOSOPHY, ANALYTICAL PHILOSOPHY, HERMENEUTICS, POST-MODERNISM, PERSONALISM, SPIRITUALISM}

We now turn our attention to another array of philosophical movements. Their common characteristic (albeit we promptly recognise this is a quite subjective classification) lies in featuring more of an emphasis on a distinctive aspect or dimension of philosophising than a doctrinal or ideological corpus proper.

\section{Pragmatism}

The first one we review here is American pragmatism. It is probably the first distinctive philosophical movement to originate in the US (hence its qualification of 'American'). In this philosophy, the truth of a notion is traced by its 'respective practical consequences ... What difference would it practically make if this notion rather than that notion were true' (James, 1907, p. 45). This assertion by James provides an effective depiction of the key emphasis of pragmatism. It is easily recognisable that it is more a philosophy of knowledge than a philosophical system tout court. It also places an emphasis on a process vision of reality as becoming, which seems to resonate deeply with the American culture: 'True ideas are those that we can assimilate, validate, corroborate and verify ... The truth of an idea is not a stagnant property inherent in it. Truth happens to an idea. It becomes true, is made true by events. Its verity is in fact an event, a process' (James, 1907, p. 201). To illustrate with an example: 'what is 90 degrees? Is it hot or cold? The pragmatist would ask, are you boiling water or are you playing basketball? The truth is in the experience, the problem and the context' (Shields, 1995). The influence of pragmatism on the development of the social sciences in the US can hardly be exaggerated, although the specific influence on PA studies is matter for finer-grained studies aimed at gleaning its distinctive influence out of a range of philosophical approaches affecting the study of this field (Snider, 2000). 


\section{Process Philosophy}

Linked to pragmatism, at least in its emphasis on becoming, is the so-called process philosophy. It is a radical ontology of becoming, whose roots can manifestly be traced in the philosophy of Alfred North Whitehead (see in particular Whitehead, 1929), an influential author, notably in the Anglophone world, but also beyond it (a Whiteheadian society is still up and running, featuring regular meetings and a kaleidoscope of initiatives, and some of its members are scholars active in the field of PA). The key notion for Whitehead is that of 'event': it is events and the becoming of things that we need to understand for gaining a deeper comprehension of reality, rather than substances; and it is interactions, mutuality of actions that shape the becoming of things - these interactions and mutuality are what Whitehead termed of 'concrescence'. ${ }^{32}$ Whitehead stresses how this philosophy is more consistent with modern physics notions of events occurring in the space-time of the Einsteinian theory of relativity as opposed to the old Newtonian physics centred on the notion of an absolute time and an inertial matter as the 'substance' of things. Research works centred on 'process accounts' are a notable feature of social scientific research in general, and political science and public administration research in particular, notably in American strands of research (one may think of the works of Abbott, 1992a, 1992b on general epistemological issues in the social sciences; Allison, 1971 in political science; and Barzelay and Campbell, 2003; Barzelay and Gallego, 2006, 2010; Asquer and Mele, 2018; amongst others in the field of PA). An interpretation of the thought of Mary Parker Follett along the lines of a Whiteheadian philosophy of becoming as its key ontological underpinning is developed by Stout and Love (2015; see also Ongaro, 2016; Stivers, 2006), drawing implications for how we conceive of public governance, on one hand, and workplace in PA, on the other hand.

\section{Analytical Philosophy}

The language turn in philosophical studies also features prominently in the 20th century. The emphasis here is on the analysis of language to frame logical-philosophical problems: Bertrand Russell and Ludwig Wittgenstein are key authors, and the universities of Oxford and Cambridge in the UK have become worldwide centres of the analytic movement and the philosophy of language. This movement is also intertwined with the developments of modern logic (in its turn intimately tied to developments in mathematics in the 19th and 20th centuries, like most notably the establishment and impressive growth of set theory, a theoretical stream associated to the thought of the mathematician Cantor and which pushed mathematics beyond its core remit of investigating the nature of numbers and of geometrical points and properties of 
space, interlinking it even further with logic), and notably with the work of the Italian logician and mathematician Giuseppe Peano as well as with the works of Frege. These developments have not gone unnoticed in the field of PA: the development of formal logic was a major intellectual aim of the philosopher Carnap and the school of Vienna, and this was a major influence on Herbert Simon, a towering figure in the field of organisation studies and PA (we elaborate more widely on Carnap's influence on Simon and PA research in Chapter 6). More recently, a thoughtful application of Frege's principles to the public administration debate about the nature of context and contextual influence in PA is developed by Bouckaert (2013). What is considered as 'modern' logic (as opposed to classical logic founded by Aristotle and centred on the syllogism) owes much to its encounter with the analytic movement, as does contemporary linguistic analysis. Subsequent developments like those brought about by Noam Chomsky are also indebted to the analytic movement. Chomsky has worked out, inter alia, the distinction between superficial structure and deeper structure of a sentence. He worked out a method to analyse the transformations whereby the deeper structure of a sentence, its non-ambiguous meaning, can be transformed into different structures, of which there are many, and that can in turn be expressed in compliance with the grammar rules of any one of the extant specific human languages that can be detected throughout the world and in history. Other key developments in contemporary language studies include the notion of 'sign' as the relation between a signifier and a signified, a notion that enjoys wide currency and extensive usage across the humanities and the social sciences in textual analyses. Analytic philosophy has acquired a notable status, highly influential if not dominant, at least in Anglophone contemporary philosophy. More limited or indirect appears the influence of this philosophical movement on PA studies. Putting it directly (and a bit simplistically), it seems there is room for importing tools and approaches from the methodologies developed within the analytic movement into the field of PA.

\section{Hermeneutics}

Hermeneutics is a philosophical movement chiefly associated with Hans Georg Gadamer (Truth and Method, 1960/1975). His work provided an approach to the interpretation of texts, based on the notions of 'pre-comprehension' and of the text seen not just as an object in front of the reader, but rather as impinging and clashing on the reader. In this perspective, the effects of a text become part of the text beyond the original intentions of the author (that the author may have intended). This configures the hermeneutical cycle. In Gadamer's philosophy there is also a re-valuation of prejudices, that he intends as pre-judgement - they are deemed to be the inevitable starting point of any approach to a text. This is a view at odds with Bacon (see Chapter 2) and much 
of the Enlightenment approach whereby philosophical reflections consists, for an important part, of erasing and rubbing away all prejudices. For Gadamer, prejudices deriving from intellectual 'authorities' are a starting point of any comprehension of a text, provided - as the Enlightenment suggested - they can be criticised rather than demanding uncritical allegiance. For Gadamer, the encounter with a book is ultimately 'making an experience' - the dialectic experience - and it is a form of knowledge well distinct from the 'collection of observations' at times acclaimed as the only starting point in knowledge generation (in opposition, for example, to positivism). Within this encounter, conceived of as ultimately an individual experience (Pareyson, 1971), truth can be attained, but truth does not exhaust itself within any one individual's existential experience and encounter with it. The hermeneutical method has been applied to a wide range of fields; this includes in legal studies and, notably in relation to the field of $\mathrm{PA}$, it is interesting to note the application of the hermeneutical method in administrative law, to the administrative procedure. ${ }^{33}$

\section{Post-modernism}

Another, and multifarious, philosophical strand goes under the label of 'Post-modernism'. It is hard to define it because the very authors working in this tradition incessantly repeat that post-modernism is undefinable. Amongst its key authors may be included the philosophers Michel Foucault, Jean-François Lyotard and Jacques Derrida. One attempt to capture some traits can be by means of a cultural-philosophical parallel of the transition from the industrial society to the information society, from material goods to information-based services, and hence from the values, premises and philosophical foundations (like positivism) of the industrial society to an undefined society where those features are no more extant but where others and new ones have not yet taken shape. It has for this reason also been defined as a combination of hypermodernity and pre-modernity (Lyotard). In the social sciences it is often associated with social constructivism (Berger and Luckman, 1966) and the hyper-accentuation of the role of the (weak) subject in construing reality, and also with forms of inter-subjectivity and inter-subjective agreement in construing society and reality at large. It enjoys a certain consolidated, although quite delimited, remit in the field of PA, with key authors, journals (mainly Administrative Theory \& Praxis) and recurring claims, which will be discussed in more detail in Chapter 4.

Often contrasted to post-modernism is critical realism (Pawson, 2006; Pawson and Tilley, 1997), centred (in our interpretation) on an attempt to combine classical realism (of Aristotelian imprint) with the role of the subject in modernity brought about by modern philosophy. This is also discussed further in Chapter 4. 


\section{Personalism}

Personalism is a philosophical movement associated with the philosopher Emmanuel Mounier, owing also to the works of Neo-Scholastic philosophers like Jacques Maritain and phenomenologists like Scheler, who applied the phenomenological method to the investigation of the essences of moral values. Personalism advocates a radical humanism and stresses the flourishing of the totality of the human person, as opposed to any reductionism, which for Mounier is any philosophy that ends up with a one-sided depiction of the human being (be it 'the economic man' or the Nietzschian 'super-human').

Mounier propounded a return to a radical humanism, a new Renaissance centred on the notion of 'person'. His thought can be better appreciated in the perspective of the polemic he engaged with both Marxism and capitalism, which for him are philosophies that ultimately operate a form of reductionism, emphasising one aspect of the human person to the detriment of its totality and entirety. For Mounier the three dimensions of the person are vocation, incarnation and communion. Vocation is the call to realise a project that each and every person has - or receives - and that for Mounier is a qualifying trait of human life. Incarnation refers to the fact that the body is always part-and-parcel of a person, contrary to those philosophical strands that tend to conceive of the human being as an abstract 'I think'. Communion refers to the perspective whereby it is only in the belonging to a community of persons that the individual person can accomplish her/himself and fully develop its vocation. It is a relational rather than atomistic conception of the human being and her/his flourishing. Communitarianism in the version propounded by Mounier is closely associated to the philosophical movement of personalism. Later in the book we query whether this perspective can enable getting beyond the common good versus social contract traditional dichotomy - this argument is developed and further discussed in Chapter 5.

But with philosophers like Carl Schmitt the notion of communitarianism went down an altogether different route: a nationalistic interpretation, whereby ethnic ties get pre-eminence. In this perspective, individual liberty must be tempered by the responsibility of the individual towards the community, conceived of at the national level, as the national community forged by ethnical or linguistic-cultural bonds. This altogether different interpretation of the notion of 'communitarianism' is also discussed in Chapter 5.

\section{Spiritualism}

Spiritualism may be seen as a distinctive stream within a larger movement that emerged between the end of the 19th century and the beginning of the 20 th across Europe, mostly - at least at its inception - as a reaction to posi- 
tivism. Spiritualism is a movement whose main tenets include the claim that philosophy cannot be absorbed into science and scientific knowledge; the consideration of the specificity of the human being, and the significance of her/his interiority, liberty, conscience; and relatedly, that introspection and conscience are part-and-parcel of any investigation of reality, and that the interiority of conscience is a door open to transcendence and God. Key authors to whom this movement refers go back in time to Plotinus and Augustine, and then to the founder of modern philosophy - Descartes - and to cultural movements that have defined epochs of Western civilisation, like Renaissance and romanticism.

An author in the spiritualist stream and the Platonic-Augustinian tradition, but whose philosophical elaboration displays highly original traits, is the French philosopher Henri Bergson, on whose philosophy we conclude the chapter and our introductory journey across Western philosophical thought. In the next chapter, the philosophical ideas introduced are applied to key issues and problems of the field of PA.

The key thrust of the philosophy of Bergson is getting a deeper understanding of life as actually lived by 'real' living beings, and notably self-conscious living beings. Against any reductionism of life to its chemical processes, he claims that life has a unity that reductionism completely misses. But how to understand this unity?

Before we turn to this, we should ponder on the rationale behind the fierce polemic that Bergson conducted against any metaphysics that conceives of entities as immersed in a present without real duration. The starting point of his philosophy is the notion of time as duration (worked out in his first major philosophical work, Essai sur les Données Immediates de la Conscience, 1913, English edition 1989). By taking the move from the lived time that each human being experiences (an approach whose methodological premise are in Descartes: the investigation of the self as the most undoubtable evidence), Bergson develops what is now a classic critique of the very notion of 'state of conscience', where the critique is to the stability or static nature implicit in the usage of the term 'state' in the expression 'state of conscience'. In fact, Bergson argues, any sensation, representation or volition that occurs in our conscience never ceases to mutate and change over time, albeit changes may be so small as to be almost imperceptible and it is only when attention is given to the accumulation of such changes that the self perceives to have transited from one 'state' of conscience to another and different 'state'. But conscience is - as vividly expressed through a very famous metaphor - a snowball. It continually grows by absorbing the future through the lived present into an ever-increasing past and, like snow for a snowball, the whole of the lived time is kept and constitutes any living being: we are the totality of our lived past. It is only for purposes of action that selectively certain 'parts' of the past are arti- 
ficially plucked and brought into the spotlight through the process of remembering, because it is the abstraction operated by intelligence that artificially distinguishes and re-aggregates moments of our life under certain abstract labels (so, our 'professional life' gets distinguished from our 'private life', our 'youth' from our elderly age, and so on). The key innovation brought about by Bergson to the philosophical thought is that for Bergson the 'self-conscious I' is an activity continuously open outside of itself (projected towards the future via the present) and 'at the same time' (so to speak) constituted by duration, that is, by the conservation of the totality of its past activity: the totality of the past of the lived time gets conserved in what is conceived of as a process of accretion. ${ }^{34}$ In Bergson's philosophy there are profound analogies with the Aristotelian notions of form and unity, but the distinctive novelty brought about by the French philosopher lies in conceiving of the time as the tissue of which every (living) being is made.

In this philosophical perspective, time is the tissue of which reality is made. Duration is the continuous advancement of the past that grows on its very activity of 'gnawing' the future, bite by bite, and yet conserving the totality of itself. The activity of remembering is an intermittent activity that occurs if and when possible, but the totality of the past does not need the activity of remembering for keeping the totality of itself: the past conserves the totality of itself by itself, and we are constituted - in other words, we are - the totality of our past. All that we have perceived, felt, thought and wanted since our infancy constitutes what we are. It is only for purposes of usefulness and practical action that our conscience rebuffs most of our past and lets only what is necessary for the purposes of the most immediate action pass to our attention. Our (as living beings) volitions, emotions or thoughts do not transit continuously from non-being back into non-being by staying an indefinitely little moment (instant) into being; instead, the totality of our past volitions, emotions or thoughts is conserved, whilst we continuously project towards the future, and the new volitions, emotions or thoughts are absorbed into our ever-growing past (which shapes what we are: what is referred to as 'our character'). Here Bergson distinguished between the time of mathematics (and physics: hence a famous contention with Albert Einstein on the nature of time) and the time of life. The time of mathematics is a spatialised time, the time of the pure instantaneity: the world, for mathematicians, dies and is born again at every instant ${ }^{35}$ this time that does not last, that has no duration, is not the real time of life. From this also derives the crucial distinction between remembering and memory: memory is the totality of our past that constitutes us. Remembering is for the action: we only remember what is required for action.

A key question addressed by Bergson is whether the living body is a body - a 'portion of matter' - like any other or not? Although it obviously occupies and carves out a piece of matter, and it can be sectioned and portioned (through 
vivisection and dissecting), the main difference between a portion of matter and a living body is that in a portion of matter the present does not contain anything more than what was already present in the causes that have determined it to reach that given status, whilst the living body lasts: its past is all contained in its present, there remaining real and active. It is for this reason that a living body passes through phases, changes and eventually gets old - because it does have a history. Bergson does not deny the fundamental identity of organic and inorganic matter, but rather the claim is that any portioning of the reality of a living body would not be the living body as such, for example a thousand pictures of Paris from any imaginable angle simply are not Paris. Anywhere there is life, a registry where time is written is open. The most immediate analogy is therefore between each living body and the universe as a whole - not portions of it - which is also constituted by the totality of its past. From this originates the idea that the universe is in continuous accretion, enhancement of the whole, in every act of will by living, organic beings (although Bergson is cautious to remind the reader that the universe as a whole is a construction, different to the 'reality' of a living being).

But what does it mean talking about 'life in general' in the frame of Bergson's philosophy? For Bergson, life is like a current, flowing from one living being to another one through the germinal cells (as outlined in his 2005 work 'L'Evolution Créatrice'). The evolution of species is thus an endogenous process: it is not caused by pre-determined efficient causes (in the Aristotelian definition of the system of four causes) because assuming these causes would be denying the reality of duration, and because all that happens would already be in the causes when they are 'present'. Nor is the evolution of species caused by final causes because analogously assuming these causes would entail that all life is simply present in front of these final causes without having a real duration (and this is a point of difference between Bergson and Leibniz, or at least the part of Leibniz's thought that was known at the time Bergson was operating). Life is a flow, like a current: famously summed up in the expression 'élan vital' ('the vital thrust').

It remains the open question of the source of this élan vital, the source of life that shapes matter, unfolds through the multiplicity of individuals and yet is a single stream that penetrates through each individual and that unites them all. Evolution occurred through the unfolding of life along different sub-streams, against the resistance of matter. One direction has brought the accumulation of energy in the vegetal world. Another direction has brought the capacity of channelling and deploying energy in the most rapid ways, like in arthropods and vertebrates. Finally, in human life a qualitative change occurred by having broken through the counter-movement of matter and having achieved the liberation of conscience. The super-conscience that is at the origin of the élan vital has in the human species liberated itself - it can now pursue liberty, free 
acts rather than the automatism of instinct. And where is mankind - and life - soaring through it? Mysticism is for Bergson the true religion that enables getting beyond the limits of humanity towards the absolute/transcendence (the theme is developed in his last work: Les Deux Sources, 1932).

Bergson by proposing a distinctive philosophical interpretation of the evolution of life (quite diverse from the one proposed by Darwin, 1859, and closer to the one proposed by other scientists, like the biologist De Vries), addresses, from a very original angle, the philosophical issue of the relation between conscience and brain (a key question in the philosophy of the mind). What is the brain for Bergson? In a famous metaphor he likened it to the blade of the dagger (conscience): the brain is not the totality of the conscience (as the blade is not the totality of the dagger, but a part of it), but it is that part that enables action. And conscience for Bergson is definitely not a product of the brain. Rather for our philosopher it is life that shapes matter - in other words, the distension of the spiritual activity is matter - not matter that makes life. Space is conceived of as extension of conscience, and matter as consolidation and inertia of acts of creation/acts of will.

Another highly innovative and original contribution by Bergson lies in his conception of intelligence and its relation with instinct. For Bergson intelligence is the capacity to classify and search for relations between things, looking at them from the outside. It is the intelligence of the natural sciences (and of most of the social sciences). Intelligence is the capacity to make use of inorganic matter by shaping it in the most functional ways. But intelligence stays at the surface of things, turns around its object without ever penetrating it (because it operates in a spatialised time where duration disappears). The capacity of penetrating the essence of things only occurs to instinct. Instinct is the faculty of utilising organic instruments for the pursuit of goals that are administered by nature itself: the eye for sight, the mouth and jaws for biting and eating, and so on. Instinct has an inner knowledge of things, but instinct by itself is blind - it can only repeat what it is apt to. Instinct and intelligence, which have a common origin and still keep trace of this commonality, are complementary: instinct drives into things, intelligence knows relationships amongst things. It is only intuition, instinct accompanied by conscience, that can get to know the things, those things that by itself intelligence can only relate. This poses a problem: that intelligence (the intelligence labelling and searching for relations) loses contact with the essence of things and their 'real life' in becoming. And isn't this an experience that many researchers, including public administration researchers, have undergone? The sense that the real life of an organisation, or a public policy process, is lost when what is sought are relations that are treated in a spatialised time that does not correspond to what happened to the real organisation, made by real, living people? According to Bergson, when time is bracketed in research work, what 
is triggered are the faculties of the intelligence, which takes multiple views of the time-less (life-less) object from the outside, for purposes of classification, detection of relations and ultimately intervention on the surveyed object for practical purposes. But life - the life of individual human beings making the organisation, and hence in a certain sense the life of the organisation as a community of living beings - gets lost, the unfolding of life in time wanes, fades away. This might be the philosophical, metaphysical underpinning of the experience researchers have when shifting from research methods intensive in contact with real lives (like ethnomethodology or case studies - especially longitudinal, thick, in-depth case studies) to research methods that require bracketing time, taking static views of people and organisations (snapshots: but a thousand pictures of Paris, even if taken from any possible spatial viewpoint, will never be Paris - as a living community made by living people).

We conclude the chapter on this famous metaphor: a thousand pictures of Paris from any imaginable angle are not Paris. We have so far hinted to possible implications of philosophical (ontological, epistemological) ideas for PA from innumerable angles, but we have not yet addressed the developments that may be brought to the field of PA by the more systematic application and examination of such ideas. It is to this task - walking the Paris of PA from within rather than hinting to it from a kaleidoscope of angles - that we turn in the next chapter.

Implications for PA/Relevance for Philosophy for PA: there are manifold implications for PA that, not unexpected, the many and so diverse streams of philosophical thought carry with them for PA. It is a purpose of this book to shed light on the potential contribution that a range of philosophical streams of thought can provide to PA: these are discussed throughout Chapters 4, 5 and 6, and from a different angle in Chapter 9.

\section{NOTES}

1. One of the few 'technical' philosophical words that we maintain in this book, hoping not to bemuse the reader, given the centrality it enjoys not just in Kant's thought but in the philosophical reflection that stemmed from it.

2. Although this notion, which seemed evident to Kant based on Newtonian physics, is not in modern physics (see, for example, the debate on 'dark matter' - its effects are felt, but it is not clear 'where' it is, and in what sense it is extended, and therefore it may be not all bodies might be 'extended'). We return to this point later.

3. The philosopher Leibniz, for example, developed a conception of space and time whereby these are conceived as 'ways in which things appears to the subject': space and time stem from the relations with which they are ordered by the subject.

4. Kant conceived of the beauty as the sentiment of order and harmony, of what is liked beyond any instrumentality associated to the object, and of the sublime as the sentiment of the infinite. Through aesthetic experience (reflective judgement, in Kant's terminology), the human being can partake through sentiment what is 
denied in terms of knowability of both the finite and the infinite. This conception will prove hugely influential on romanticism.

5. In the sentence 'our' refers to we humans as rational beings.

6. This truly embodies the spirit of the Enlightenment, which Kant so powerfully brought to vertiginous heights.

7. Kant never reduced reality to the phenomenon; rather he postulated that phenomena are the perimeter of human knowledge.

8. The thinking subject is the main point of departure of philosophising since Descartes; however, Kant like Descartes before him and many other philosophers later on have struggled to come to grips with the nature and foundation of the unity of the thinking subject.

9. Fichte had the highest esteem of Kant, and he even hints in this works that maybe Kant did not reveal the consequences of his thought (consequences that Fichte was claiming to now be shedding light on) because he (Kant) possibly did not consider his times ripe enough for people to understand the revolution that was on the verge of being brought about.

10. This is the interpretation Hegel gave to his thought: as we have already seen, Schelling's thought should not be seen as just one phase towards the Hegelian philosophy; moreover, Schelling transformed quite radically his thought more than once over his lifetime.

11. The philosophy of nature was centre stage during the epoch of the romanticism, of which Schelling was an influential exponent.

12. Different from pantheism that assumes that God is everything.

13. I am indebted to Wolfgang Drechsler for having pointed out this three-fold meaning of the German term aufheben and its usage in Hegel's dialectic.

14. To better set Hegel's statement in context, it is important to notice that Aristotle conceived of the infinite (in mathematical terms) as a potentiality, not an actuality (a notion that can be conceived of in potentiality but can never actually occur), and this has been the prevailing wisdom over two millennia, and still was at the time of Hegel. Later in the 19th century, the German-Russian mathematician Cantor argued that, under certain formal definitions of the concept of infinite, the notion of infinite as a mental entity could be thought to exist in actuality; indeed, Cantor even argued that there be different orders of infinite, that is, in a bit of a vulgate, over-simplistic expression, that some infinites are 'more infinite' than others, meaning that an infinite defined in such a way to be obtained through a certain mathematical process is, according to Cantor's theory, of a higher order than another one (however counterintuitive it may prima facie be).

15. Part of this argument is masterfully delineated in an earlier work of Hegel, which many commentators deem to have embodied heights unparalleled in the rest of his production: Phenomenology of Spirit (1807/1977).

16. It is very difficult to refer to something like 'the original thought of Marx' - in fact his philosophy has been subjected to multifarious readings and used as source of inspiration to carry out massively impactful social experiments across the world. It is nowadays virtually impossible to disentangle an 'original' thought from such array of interpretations and experiments.

17. According to this perspective, theology originates in anthropology.

18. The notion of alienation was already in Hegel, defined as the objectivisation of the ideal that when it meets the material world becomes 'other' from the subject who acted in the pursuit of it. For Hegel, alienation is inherent to the process of objectivisation, as a resultant of a dialectical process. Hegel gave a larger ontological 
meaning to the notion of alienation than Marx. For Marx, alienation was a deviant product of society; for Sartre, any social act becomes modified by the other(s) and the very encounter with materiality, and for this very reason the meaning of the act is modified and its concrete manifestation 'becomes' other than that the subject initially wanted through the act - the act becomes stranger to the will who pursued the act, feeds back becoming alien to the will, and hence the process of alienation.

19. It may be interesting to notice that the most famous work (alongside the Manifesto of the Communist Party, 1848) by Karl Marx, The Capital (1867), was written in a world capital of capitalism like London, where Marx lived after he was exiled from Germany, France and Belgium, toiling to earn a living and with almost no livelihood but the support and the help of his lifelong friend Friedrich Engels (who edited the second and third volumes of The Capital after the passing away of Marx). Engels's original thought is also a key inspiration for Soviet Marxism.

20. Many of us scholars, who uphold intellectual independence as a condition for the exercise of the research work only at the service of the search for truth, may well find this interpretation of the role of intellectuals repugnant.

21. A notion Schopenhauer derived from Indian philosophical thought, notably the Upanishad, with which Schopenhauer was in contact through the frequentation of the orientalist Friedrich Mayer.

22. The incomplete notes for a projected book 'The will of power' that Nietzsche never finished were later arbitrarily manipulated and interpreted as justification of the pursuit of power by the strongest, and furnished ideological backing to Nazism. Although this is probably not what Nietzsche would have meant (because he fiercely opposed any philosophical 'system' and the very idea that one principle can explain reality, and because his concerns were more about furnishing a sense to a barren post-Christian existence: his focus was more on individuals desperate about how to live one's own life after 'the death of God', and all his philosophy is very far from entrusting any salvation power to the State), but when irrational will and the orgiastic dimension of life become prominent and acquire a salvific status, the risks of fatal drifts arise.

23. On a more subtle interpretation, it may be argued that perhaps Nietzsche intended that one has to choose to live 'as if' everything recurred the same infinitely, so that she/he might 'take control' of her/his destiny by accepting its necessity.

24. 'questo mondo civile egli certamente è stato fatto dagli uomini, onde se ne possono, perché se ne debbono, ritruovare i principi dentro le modificazioni della nostra medesima mente umana' ('This civil world [that is, society] has certainly been made by humans, and it is for this reason that it is possible, and we must, discover its principles within the modifications of our own human mind' -Vico (1725).

25. The notion of disenchantment of the world is another key notion elaborated by Weber, which we cannot even touch upon here. It is the progressive intellectualisation of the way in which humankind investigates the world, and the problem of the meaning of the world - and of our presence in the world - which scientific reason will never be able to respond to.

26. Indeed, it was the discussion on the famous fifth postulate of Euclidean geometry that sparked the debate about whether a foundation of geometry (and sciences more at large) on 'undoubtable', self-evident truths could be established, or whether the starting points of geometry (as well as the sciences) can 'only' be attributed the status of mere 'conventions'. In the Euclidean tradition, self-evident truths are referred to as either 'axioms' (assumptions valid in geometry as well as 
across fields of knowledge) or postulates (self-evident truths typically pertaining to geometry) - and conventionalism questions the very notion of 'self-evident truth'.

27. At least partly because recent developments in physics seem to expand the scope of application of quantum theory.

28. We should also add another caveat, derived from a renaissance thinker: Guicciardini who is notable for his empiricism to which he added a strong caveat towards the challenges of generalising from induction: 'È grande errore parlare delle cose del mondo indistintamente e assolutamente e, per dire così, per regola; perché quasi tutte hanno distinzione e eccezione per la varietà dellle circunstanze, le quali non si possono fermare con una medesima misura; e queste distinzione e eccezione non si truovano scritte in su' libri, ma bisogna le insegni la discrezione' ['It is a huge mistake to make judgements about the things of the world based on law-like generalisations, in a way that is indistinct and absolute; because almost in anything there is the need to distinguish and find out the exceptions to the rule, which depend on the varied circumstances; and such varied circumstances cannot be treated in a one-size-fits-all way; in order to learn how to distinguish the varied circumstances and spot the exceptions it is necessary to wield discretion, because this know-how cannot be learnt in books'], Ricordi, n.6 (online at: https:// letteritaliana.weebly.com/discrezione-e-fortuna.html - accessed 7 April 2020).

29. At the end of his search Martin Heidegger will also go back to the pre-Socratics, that is the philosophers before Socrates, Plato and Aristotle, for discovering the unveiling of the mystery of being, and he will thus in a sense reject both classical and modern philosophy.

30. There is here a strong influence of the 19th-century Danish philosopher Soren Kierkegaard, considered a precursor of existentialism and whose philosophy is centred on the critique of the metaphysical category of necessity as constitutive or inherent of Being, as in the Hegelian, and before the Spinozian, system of philosophy.

31. There are manifold definitions of structure, and debates on the meaning of the term 'structure' are countless. One that may suffice for the purposes of the present introduction is that of structure as 'a system of self-regulating transformations' (e.g. Piaget).

32. Parallels may be drawn between Whiteheadian notion and the seminal reasons of change worked out in ancient Greek philosophy especially by Stoic philosophers. As the readers will have noticed, and to the risk of repeating this point as a refrain, it is a key emphasis of this book to stress how taking the broad and long-term philosophical perspective may be enlightening in contextualising and setting in perspective modern and contemporary thinkers.

33. I am indebted to Fabrizio Fracchia for having pointed out this line of application of the hermeneutical method of direct relevance to PA studies.

34. This approach distinguishes his philosophy from Descartes's, and is a very insightful way of addressing a range of critiques that were moved to Descartes, including the one by Locke's (in his Essay) where he distinguished between the 'self-conscious I' and the observable qualities of its activity, or the criticisms by Maine de Biran where he highlights how the Cartesian 'I' is a purely passive substance, a sort of blackboard recipient of what is thrown over it.

35. From which, for Bergson, Descartes erroneously derived his notion of continued creation - from a creationist perspective, the partaking of being by the contingent 
entities as a gift of the absolute Being is maintained by living beings as they are the totality of their past. 